Isabela Santos de Albuquerque Nunes

A cooperação internacional de política e desenvolvimento do governo alemão em parceria com os países da América Latina Como exemplo: O desempenho da Iniciativa Somos Mercosul

O balanço da Iniciativa Somos Mercosul no ano de 2009, desenvolvimento, barreiras e perspectivas para 2010.

Brasília 
Isabela Santos de Albuquerque Nunes

A cooperação internacional de política e desenvolvimento do governo alemão em parceria com os países da América Latina

Como exemplo: O desempenho da Iniciativa Somos Mercosul

\begin{abstract}
Monografia apresentada junto ao Curso de Especialização em Relações Internacionais da Universidade de Brasília, na área de Relações Internacionais, como requisito para a obtenção do título de Especialização
\end{abstract}

Orientador Prof.Virgilio Arraes

Brasília

2010 


\title{
A cooperação internacional de política e desenvolvimento do governo alemão em parceria com os países da América Latina Como exemplo: O desempenho da Iniciativa Somos Mercosul
}

\author{
Monografia apresentada junto ao \\ Curso de Especialização de Relações Internacionais \\ da Universidade de Brasília, na área de Relações Internacionais \\ como requisito para a obtenção para o título de Especialização
}

Orientador Prof. Virgilio Arraes

COMISSAO EXAMINADORA

1. Prof. Virgílio Arraes

Universidade de Brasília

2.

Universidade de Brasília

3.

Universidade de Brasília

Brasília, 02.04.2010 


\section{Resumo}

O presente trabalho procura analisar o desempenho da Iniciativa Somos Mercosul, uma cooperação para o desenvolvimento entre os países do Mercosul, a sociedade civil da região e o Governo Federal da República da Alemanha. A Iniciativa Somos Mercosul foi criada em 2003 durante a presidência do Uruguai no Mercosul. Seu objetivo é aproximar os cidadãos comuns das decisões do Mercosul, por meio da promoção do diálogo direto e da divulgação das ações do bloco. Além disso, a iniciativa é um canal para o exercício da cidadania nos países integrantes do Mercosul e uma fonte de informação sobre o processo de integração do bloco sul-americano.

3 palavras chaves: cooperação, Iniciativa Somos Mercosul e integração 


\section{Resumo}

El presente trabajo busca muestra el desarrollo del ano de 2009 de la Iniciativa Somos Mercosur, una cooperación para el desarrollo entre los países del Mercosur, la sociedad civil e el Gobierno Federal de la República de la Alemana. La Iniciativa Somos Mercosur fue llamada a la vida en 2003 en la presidencia de Uruguay en el Mercosur. El objetivo de la iniciativa es aproximar sociedad civil y el gobierno, y que por medio de sus diálogos y la divulgación de las acciones del bloco. Además, la iniciativa es un canal para el ejercicio de la ciudadanía en los paise integrantes del Mercosur y una fuente de información sobre el proceso integrativo del bloco sulamericano. 


\section{Abreviaturas}

\begin{tabular}{|c|c|}
\hline $\mathrm{ABC}$ & Agencia do Brasil de Cooperação \\
\hline ALADI & Associação Latino-Americana de Integração (Port.) \\
\hline ALAMPYME & Associação Latino-Americana de Micro, Pequena e Medias Empresas \\
\hline ALC & América Latina e Caribe \\
\hline ALCA & Área de Livre Comércio das Américas (Port.) \\
\hline APD & Ajuda Pública ao Desenvolvimento \\
\hline BID & Banco Interamericano de Desenvolvimento \\
\hline BMZ & Ministério Federal para Cooperação Econômica e para Desenvolvimento \\
\hline CARICOM & Comunidade do Caribe \\
\hline $\mathrm{CCM}$ & Comissão de Comercio do Mercosul \\
\hline CEFIR & Centro de Formação para a Integração Regional \\
\hline CELARE & Centro Latinoamericano para as Relações com a Europa \\
\hline CEPAL & Comissão Econômica para América Latina e o Caribe \\
\hline CCSS & Conselho Consultivo da Sociedade Civil \\
\hline CID & Cooperação Internacional para o desenvolvimento \\
\hline CIM & Centro de Migração Internacional e Desenvolvimento \\
\hline $\mathrm{CMC}$ & Conselho do Mercado Comum \\
\hline $\mathrm{CPC}$ & Comissão Parlamentaria Conjunta \\
\hline CRPM & Comissão de Representantes Permanentes do Mercosul \\
\hline DED & Serviço Alemão de Desenvolvimento \\
\hline DEG & Coorporativa Alemã de Investimento e de Desenvolvimento \\
\hline EUA & Estados Unidos da América \\
\hline FCES & Foro Consultivo Econômico-Social \\
\hline FESUR & Fundação Friedrich Ebert no Uruguai \\
\hline FLACSO & Faculdade Latino-Americana de Ciências Sociais \\
\hline FMI & Fundo Monetário Internacional \\
\hline FOCEM & Fundo para a Convergência Estrutural do Mercosul \\
\hline GMC & Grupo do Mercado Comum \\
\hline GTZ & Agência Alemã de Cooperação Técnica \\
\hline IDH & Índice de Desenvolvimento Humano \\
\hline IDE & Investimento Direto Estrangeiro \\
\hline IPH & Índice de Pobreza Humana \\
\hline FMI & Fundo Monetário Internacional \\
\hline InWent & Empresa Internacional de Formação e Desenvolvimento \\
\hline KAS & Fundação Konrad Adenauer \\
\hline KFW & Banco de Desenvolvimento \\
\hline MERCOSUL & Mercado Comum do Sul (Port.) \\
\hline OECD & Organização Econômica para Cooperação e Desenvolvimento \\
\hline$O E C E$ & Organização para a Cooperação Econômica Européia \\
\hline OMC & Organização Mundial de Comércio \\
\hline ONU & Organizações das Nações Unidas \\
\hline ONGs & Organizações Não-Governamentais \\
\hline OPEP & Organização dos Países Exportadores de Petróleo \\
\hline PARLASUL & Parlamento do Mercosul \\
\hline PIB & Produto Interno Bruto \\
\hline PNB & Produto Nacional Bruto \\
\hline POP & Protocolo de Ouro Preto \\
\hline PRSC & Poverty Reduction Support Credit \\
\hline RBCE & Revista Brasileira de Comércio Exterior \\
\hline Red Mercociudades & Rede de Mercocidadaes \\
\hline RECM & Reunión Especializada das Cooperativas do Mercosul \\
\hline RSE & Responsabilidade Social Empresarial \\
\hline SAM & Secretaría Administrativa del MERCOSUR \\
\hline SM & Secretaria do Mercosul \\
\hline SELA & Sistema Económico Latinoamericano \\
\hline SM & Secretaría del MERCOSUR \\
\hline UE & União Europeia (Port.) \\
\hline UNASUL & União de Nações Sulamericanas \\
\hline
\end{tabular}




\section{Sumário}

Introdução

1. O que é uma Cooperação para o Desenvolvimento? 15

1.2 Cooperação para o Desenvolvimento na União Européia - Alemanha 20

1.2.1 A Cooperação para o Desenvolvimento na Alemanha 27

$\begin{array}{ll}\text { 1.2.1.1 Objetivos } & 29\end{array}$

1.2.1.2 Temas e princípios $\quad 29$

1.2.1.3 Meios e atores 31

1.3 Cooperação alemã na América Latina 35

1.3.1 Cooperação alemã no âmbito do Mercosul 38

2. Iniciativa Somos Mercosul 41

2.1 A definição da Iniciativa Somos Mercosul 42

2.2 Presidência Pro Tempore 44

2.3 A estrutura do Somos Mercosul 45

2.3.1 Somos Mercosul, Argentina 45

2.3.2 Somos Mercosul, Brasil 47

2.3.3 Somos Mercosul, Paraguai 49

2.3.4 Somos Mercosul, Uruguai e Cefir 50

2.3.5 Objetivos do governo alemão com a cooperação 52

2.3.6.1 Financiamento da cooperação alemã para o desenvolvimento 54

3. O resultado da Iniciativa Somos Mercosul 2009

3.1 Balanço Somos Mercosul 2009

3.2 Mecanismos desenvolvidos para a participação da sociedade civil promovida pela

Iniciativa Somos Mercosul 59

3.2.1 Boletim Somos Mercosul 60

$\begin{array}{ll}\text { 3.2.2 Cimeira Social } & 63\end{array}$

3.3 Obstáculos à Iniciativa Somos Mercosul 66

4. Conclusão e a oportunidade para o trabalho do projeto Somos Mercosul em $\begin{array}{ll}\text { conjunto com o governo alemão } & 71\end{array}$

$\begin{array}{ll}\text { Bibliografia } & 78\end{array}$

1. Jornais 78 
$\begin{array}{ll}1.1 \text { Argentina } & 78\end{array}$

$\begin{array}{ll}1.2 \text { Brasil } & 78\end{array}$

$\begin{array}{ll}1.3 \text { Chile } & 78\end{array}$

$\begin{array}{ll}1.4 \text { Alemanha } & 78\end{array}$

$\begin{array}{ll}1.5 \text { Paraguai } & 78\end{array}$

$\begin{array}{ll}\text { 1.6 Uruguai } & 78\end{array}$

2. Monografias e ensaios $\quad 79$

3. Páginas de Internet 81 
"Não cabe, todavia, perder a esperança, porque os progressos técnicos obtidos neste fim de século 20, se usados de uma outra maneira, bastariam para produzir muito mais alimentos do que a população atual necessita e, aplicados à medicina, reduziriam drasticamente as doenças e a mortalidade.

Um mundo solidário produzirá muitos empregos, ampliando um intercâmbio pacífico entre os povos e eliminando a belicosidade do processo competitivo, que todos os dias reduz a mão-de-obra. É possivel pensar na realização de um mundo de bemestar, onde os homens serão mais felizes, um outro tipo de globalização." 1

\footnotetext{
${ }^{1}$ Santos, Milton. Texto: Por uma globalização mais humana. Folha de São Paulo. São Paulo, 2001.
} 


\section{Milton Santos}

\section{Introdução}

Desde a Segunda Guerra Mundial, observa-se a necessidade de uma transformação na arquitetura financeira internacional. Dentro desse processo está a noção de "Ajuda ao Desenvolvimento" ou "Cooperação para o Desenvolvimento", segundo a qual países, em sua maioria "desenvolvidos", ajudam financeiramente, com tecnologia e com recursos estruturais e humanos àqueles que se encontram em processo de desenvolvimento. Termo criado na época da reconstrução da Europa com a aplicação do Plano Marshall, esse programa restringia-se na época ao desenvolvimento econômico, mas atualmente ele teve seu conceito reformulado ${ }^{3}$. A idéia de ajuda ao desenvolvimento expandiu-se em direção a uma visão mais complexa de "bem público global", ou seja, pertencente a todos. Tal visão direciona-se à criação e à preservação do conjunto de direitos humanos voltado para todos, em especial para a população dos países em transformação.

O conceito de Cooperação para Desenvolvimento abre questões sobre os direitos de todos os povos ao desenvolvimento, à paz e a um meio ambiente limpo. Neste trabalho, lanço um ponto de vista sobre a necessidade de um debate sobre a eficácia dessa ajuda oficial entre países, que é desdobrada pela Declaração de Paris, pela Agenda de Ação em Acra e pelas Metas do Milênio. Esses documentos reabrem a discussão e reafirmam o convencimento de que ajuda aos chamados "países em desenvolvimento" " não seria eficaz somente porque pode resolver problemas técnicos

\footnotetext{
2 As aspas nas palavras "desenvolvidos" e "em desenvolvimento" serão utilizadas aqui para diferenciar os países "em desenvolvimento" de "países desenvolvidos". Esse último termo faz referência aos países fortemente industrializados, com grande poder econômico, alto Índice de Desenvolvimento Humano (IDH) e cuja população possui elevado padrão de vida. Apesar de existirem diferentes níveis de riqueza dentro desses países ditos desenvolvidos, esses não são tão díspares quanto nos países em transformação.

${ }^{3}$ O novo conceito da OCDE para sua Cooperação para o Desenvolvimento é de promover políticas que assegurem o crescimento econômico sustentável e o emprego, a qualidade de vida e a liberalização do comércio. O conceito de crescimento econômico sustentável da OCDE tenta equilibrar os aspectos econômicos, sociais e ambientais do desenvolvimento.

${ }^{4}$ País em desenvolvimento, país em transformação ou país emergente são termos geralmente usados para descrever um país que possui uma população com um padrão de vida relativamente baixo, uma base industrial em desenvolvimento e um Índice de Desenvolvimento Humano (IDH) variando entre médio e baixo. A classificação dos países é difícil, visto que não existe uma única definição internacionalmente reconhecida do termo, "país desenvolvido", e os níveis de desenvolvimento
} 
ou metodológicos dos países receptores da cooperação. Diferentemente disso, a Declaração de Paris, a Agenda de Ação em Acra e as Metas do Milênio insistem que realização da cooperação para o desenvolvimento é um direito de todos países e de todos cidadãos do planeta.

Países de renda média, entre os quais se inclui a maior parte da América Latina, escondem o principal problema da região: a profunda desigualdade social. Algumas regiões latinas possuem níveis de pobreza piores que os registrados em certos países africanos, onde estão os mais alarmantes indicadores sociais do mundo. Depois dos anos 80, conhecidos como a década perdida, e por conta do desenvolvimento, da estabilização e do crescimento econômico e financeiro da região, essa realidade vem sendo processualmente esquecida pelos planos e pelos projetos da maioria dos financiadores (instituições ou países) das cooperações para desenvolvimento. Após o "relançamento do Mercosul", , os países da região, em especial aqueles do Cone $\mathrm{Sul}^{6}$, conheceram um crescimento econômico e uma notoriedade na política internacional. Desde então, a desigualdade social que impera ali se tornou invisível. Os financiadores de cooperações passaram então a deixar a região, argumentando que seu produto interno bruto per capita já não justificava a sua presença e o seu apoio ${ }^{7}$.

O governo federativo da Alemanha é um dos países que ainda acredita na necessidade de revitalização da região. Apesar de ter reduzido sua participação em projetos voltados para a América Latina, a Alemanha investe na reformulação dos temas a serem trabalhados ali. Entre suas principais preocupações estão a floresta tropical (sobretudo o território da Amazônia), o meio ambiente, a necessidade da energia renovável, a sobrevivência das comunidades indígenas e o Global Governance. A

econômico e social podem variar muito dentro do grupo dos "países em desenvolvimento". [ Sullivan, Arthur. Economics: Principles in Action .Upper Saddle River, New Jersey 2002. Pg. 471]

${ }^{5}$ O Mercosul é o Mercado Comum do Sul. O bloco foi constituído em 1991 com a assinatura do Tratado de Assunção. Formado inicialmente por Uruguai, Paraguai, Argentina e Brasil, o Mercosul ganhou em 2006 a adesão da Venezuela. No final da década de 1990, o desenvolvimento do bloco estagnou-se. Em 2000, foi proclamada pelos Estados membros uma nova etapa de integração regional, chamada então de "revitalização" ou "restart" do Mercosul.

${ }^{6}$ O Cone Sul é entendido como a região que engloba Chile, Argentina, Uruguai e os estados brasileiros do Rio Grande do Sul, Santa Catarina, Paraná e São Paulo. Algumas vezes se inclui também o Paraguai. Fonte: Wikipédia, fev.2010. Disponível em: http://pt.wikipedia.org/wiki/Cone_Sul. Acesso em: 12 fev. 2010

${ }^{7}$ Indicadores de Desenvolvimento do Milênio. Banco Mundial e ONU, dez 2008. Disponiível em: http://mdgs.un.org/unsd/mdg/Host.aspx?Content=Data/Regional/latin.htm. Acesso em: 20 fev. 2010 
cooperação entre os governos da região do Cone Sul e da Alemanha se constitui em uma troca de experiências entre um bloco - a União Européia, que tem 50 anos de experiência na questão da expansão da integração regional - e outro, o Mercosul.

Um dos mais bem-sucedidos projetos da Alemanha na América Latina é o Somos Mercosul, o qual é tema do presente trabalho. Criada durante um discurso do presidente do Uruguai, Tabaré Vázquez, em 2005, a Iniciativa Somos Mercosul é desenvolvida por quatro governos do Mercosul (Argentina, Brasil, Paraguai e Uruguai) em conjunto com a Agência Alemã para Treinamento e Desenvolvimento (InWent) e a fundação política Friedrich Ebert.

O principal objetivo da iniciativa é aproximar os países membros do Mercosul e assim criar uma espécie de identidade "mercosuliana". Os dois últimos componentes InWent e a fundação política Friedrich Ebert - têm o papel de intercambiar suas experiências passadas com a União Européia e de abrir uma plataforma de discussão com os outros países (Argentina, Brasil, Paraguai e Uruguai).

O projeto Somos Mercosul abriu um novo espaço regional e transnacional de cooperação. O surgimento de governos com políticas mais direcionadas para o social estendeu o pano de fundo para o sucesso do seu desenvolvimento. Em contraste com os recentes acordos de integração latino-americana, o Mercosul tem de fato levado a um desenvolvimento do processo de reaproximação cultural e hoje é considerado como um dos movimentos mais significativos de integração das economias emergentes. ${ }^{8}$

No entanto, questionamos aqui: A iniciativa tem colaborado de fato com o objetivo do Mercosul de aprofundar a integração regional entre seus Estados-Membros? Por que o governo da República Federativa da Alemanha promove essa cooperação? Ela trouxe resultados mais positivos ou mais negativos para a região? Em que medida a Iniciativa Somos Mercosul contribui para o trabalho de integração realizado pela sociedade civil organizada e pelos governos da região? Que avaliação se faz da

\footnotetext{
${ }^{8}$ Pereira, Marcelo. Ser y Parecer. Balance de la Initiativa Somos MERCOSUR. Anális y Propuestas. Stiftung Friedrich Ebert, Montevideo 2006. Pag. 2-5.
} 
iniciativa? Esses questionamentos são a base deste trabalho, cujo tema começou a ser desenvolvido em minha monografia de graduação. Esta nova reflexão tem evidentemente um novo enfoque, que parte não do Mercosul, mas da visão do cooperador externo, o governo da República Federativa da Alemanha.

Até hoje, não existe uma documentação detalhada sobre o Somos Mercosul, projeto no qual a Alemanha se engaja. Por esse motivo, o atual trabalho tem grande relevância para o levantamento da documentação do processo de integração regional atual. A falta de informação e transparência do Mercosul dificultou a criação de uma documentação apropriada, o que foi tentado muitas vezes pelas instituições não governamentais ligadas ao projeto em questão, sem sucesso. Para obter conhecimento dos processos e do desenvolvimento da iniciativa, realizei no segundo semestre de 2008 um estágio na Secretaria Técnica e sede do projeto Somos Mercosul (Cefir), no Uruguai, na cidade de Montevidéu. No Cefir, participei de seminários, conferências e reuniões entre os governos, as instituições cooperantes e a sociedade civil, além de ter tido a oportunidade de pesquisar em documentos públicos da iniciativa. Realizei também entrevistas entre representantes dos governos e das instituições nãogovernamentais imbricados ao projeto.

Apresentamos inicialmente uma visão geral da Cooperação para o Desenvolvimento entre América Latina e a República Federativa da Alemanha, desde sua criação até o estabelecimento do novo modelo de cooperação. Aqui, é dada especial atenção às mudanças no âmbito do desenvolvimento do projeto, à sua reformulação e ao estabelecimento de novos temas de enfoque. Partiremos, então, para o alvo deste trabalho: os projetos dentro do âmbito do Mercosul com aspirações de melhorar a integração regional, principalmente com a participação da sociedade civil em conjunto com os governos dos quatro países membros do bloco. ${ }^{9}$

A revitalização do Mercosul e de sua política econômica traz uma nova visão sobre as questões de integração que deve ser esclarecida. Na segunda parte do texto tratamos então de apresentar um exemplo de cooperação multilateral em processo na região, a

\footnotetext{
${ }^{9}$ O governo da República Bolivariana da Venezuela entrou em 2006 com um requerimento para aderir como membro pleno do Mercosul, ainda em processo de votação nas casas congressuais dos países membros plenos do bloco em questão. (Nota do autor)
} 
iniciativa Somos Mercosul. Porque o projeto foi criado e com que objetivos? Esses são alguns Pontos que tentamos esclarecer até chegar à abordar seus desafios, entre os quais está a questão de Governo versus organizações da sociedade civil, bem como os respectivos temas abordados dentro processo de integração.

A decisão de iniciar uma pesquisa sobre o Somos Mercosul me veio após uma série de estudos sobre programas de integração no bloco Mercosul. Desde sua criação, essa iniciativa se configura como uma das poucas a apresentar uma forma "direta" de referência e de participação de todos os governos dos países membros. O atual equilíbrio, a estabilidade e as estruturas nos âmbitos cultural, social, político e econômico de cada país membro são tomados em consideração pelo Somos Mercosul e são portanto apresentados nesse trabalho. Um dos maiores objetivos desse programa é a institucionalização e a afirmação da participação da sociedade civil no processo de integração por meio da Cúpula Social do Mercosul. A reunião acontece a cada seis meses e precede a cúpula presidencial do bloco. A primeira tem o papel de organizar e trazer os temas importantes para a população para a esfera presidencial.

$\mathrm{Na}$ terceira parte, explanamos o desenvolvimento prático da iniciativa, com base nas abordagens apresentadas e avaliadas. A análise se concentra na evolução social e cultural, no desenvolvimento e nos seus efeitos sobre a criação de um espaço para a participação da sociedade civil do ano de 2009.

Como método de investigação, lançamos mão de entrevistas com políticos e atores da sociedade civil, quando questionamos sobre a definição e a composição da iniciativa Somos Mercosul e sobre como ela é implementada em colaboração com outras organizações internacionais. Outra fonte em que se baseia o presente trabalho são as conferências e seminários realizados na sede do Cefir, na Secretaria do Mercosul e no âmbito do programa da Fundação Friedrich-Ebert no Uruguai (Fesur). A literatura utilizada aqui se compõe de documentos sobre o Somos Mercosul e de textos de autoria de especialistas da região sobre o tema integração. Além disso, foram consideradas as relações individuais e as estruturas da iniciativa em cada país. Essa etapa do trabalho termina com uma análise sobre as Cúpulas Sociais realizadas no ano de 2009. Essa reflexão se apóia nos documentos finais da Cúpula Social. 
A parte final do trabalho contém a conclusão resultante do balanço feito sobre a iniciativa e sobre a cooperação da Alemanha. Além disso, são apresentadas as perspectivas para 2010 da referida iniciativa e suas propostas de soluções para as dificuldades. A intenção é com isso colaborar para o aperfeiçoamento da próxima presidência Pro Tempore do Mercosul.

\section{O que é uma Cooperação para o Desenvolvimento?}

A Cooperação Internacional para o Desenvolvimento ou Cooperação para o Desenvolvimento constitui importante instrumento de desenvolvimento, auxiliando países a promoverem mudanças estruturais nos seus sistemas produtivos, como forma de superar restrições que tolhem seu crescimento. Os programas implementados sob a égide dessas cooperações permitem transferir conhecimentos, experiências de sucesso e sofisticados equipamentos, contribuindo assim para capacitar recursos humanos e fortalecer instituições do país receptor, e possibilitando-lhes salto qualitativo de caráter duradouro. ${ }^{10}$ Exatamente por conta do seu caráter de longa duração, essas iniciativas se diferenciam das ajudas humanitárias, que são feitas depois de crises, guerras, conflitos sociais ou catástrofes naturais. As formas de cooperação para o desenvolvimento são variadas, incluindo uma grande diversidade de recursos quanto à origem e à natureza. Aqui, nos restringiremos a falar de quatro desses recursos, considerados os mais importantes e até hoje os mais usados em ações de Cooperação para o Desenvolvimento:

\section{- As formas de recursos para o desenvolvimento:}

1. Ajuda Pública ao Desenvolvimento (APD): cooperação técnica, ajuda alimentar, alívio da dívida, apoio ao orçamento, etc;

2. Outros Recursos Oficiais (OFO): empréstimos, créditos e exportação, etc;

3. Donativos por meio das Organizações Não-Governamentais (ONGs);

4. Recursos Privados.

A cooperação técnica internacional desperta grande interesse num amplo segmento da

\footnotetext{
${ }^{10}$ Agência de Cooperação do Brasil (ABC). Introdução, Brasília 2010. Disponível em: http://www.abc.gov.br/ct/introducao.asp. Acesso em: 10 fev. 2010
} 
sociedade - setores governamentais, ONGs e o público em geral - por possibilitar um acesso mais ágil à tecnologias, conhecimentos, informações e capacitação. Os países "em desenvolvimento" da América Latina vêm trabalhando em parceria com "nações amigas ou com relações diplomáticas" e organismos internacionais há cerca de quatro décadas. Os projetos de cooperação técnica vêm produzindo benefícios em importantes setores como transportes, energia, mineração, meio ambiente, agricultura, educação e saúde, o que permitiu construir instituições mais sólidas, aptas a desempenhar suas funções em nível superior de excelência.

A compreensão de política de desenvolvimento de um país ou instituição e a compreensão de seu engajamento pressupõem um conceito de desenvolvimento, cujos princípios definem as alternativas e os métodos a serem introduzidos em determinado contexto, com o objetivo de modificar uma situação "desvaforável” de um país ou região em questão. De acordo com a maioria das instituições ou dos governos cooperantes, desenvolvimento é concebido como um processo de superação da fome, da pobreza, de doenças, de desigualdades e de estruturas de poder que violam a dignidade e os direitos dos seres humanos e que impedem o controle sobre os recursos necessários à sobrevivência. A implementação desse conceito tem como motivo tratar de modificar a estrutura social. Trata-se de apoiar pobres, desfavorecidos e oprimidos a saírem dessa condição. A pergunta fundamental é, entretanto, como ajudar os "os que ainda estão em desenvolvimento" dentro do processo de crescimento econômico, financeiro, social, técnico e, ou político?

Um aspecto importante no conceito de desenvolvimento, principalmente no que se refere ao ponto de vista do governo alemão, é a busca da participação das pessoas envolvidas nos processos decisórios, ou seja, os governantes. Para os alemães engajados no programa, os governantes estariam capacitados a melhorar as condições de vida da população do seu país com responsabilidade, por meio de um debate que envolvesse também a população e a sociedade civil organizada. A partir dessa aproximação, eles teriam conhecimento das verdadeiras necessidades dos eleitores. Dentro dessa perspectiva, as visões dos países do sul constituem parte integrante da concepção de participação conjunta do governo, da sociedade e dos cooperantes afim 
de que sejam alcançados os resultados da Cooperação para o Desenvolvimento. ${ }^{11}$

Desde quando lançado o tema da cooperação para o desenvolvimento e até os anos 1990, se acreditava que o "desenvolvimento" seria uma conseqüência do crescimento puramente econômico e financeiro ${ }^{12}$. O objetivo de uma política eficaz de desenvolvimento deveria ser o crescimento do PIB - Produto Interno Bruto - e a estabilização financeira de um país, sendo que a distribuição da renda sequer era questionada. A industrialização, alicerçada no modelo dos países "industrializados"13, de acordo com essa vertente de pensamento ortodoxo, geraria maior riqueza e conseguiria impulsionar a saída de um país do contexto de "subdesenvolvimento". A idéia parece muito simples: primeiro é necessário que a "riqueza econômica do país" cresça, para que, em seguida, possa ser distribuída. Essa segunda etapa, porém, fora sempre pouco questionada. Desde então, com o crescimento do seu bolo, países passaram a ser caracterizados como "em desenvolvimento e emergentes". As expectativas eram de que viessem a se desenvolver segundo o modelo dos "desenvolvidos", onde houve uma maior divisão de renda entre a população. Durante esse processo, os países mais ricos seriam obrigados a ajudar os "ainda em desenvolvimento", indicando-lhes o melhor caminho para o crescimento.

Em contraposição à concepção anterior, foi criado em 1990 o Índice de Desenvolvimento Humano (IDH) ${ }^{14}$, fruto do trabalho dos economistas Amartya Sen e Mahbub ul Haq. O IDH vem sendo usado desde 1993 pelo Programa das Nações Unidas para o Desenvolvimento no seu relatório anual. Em 1997, foi introduzido o

\footnotetext{
11 Andrioli, Antônio Inácio . Desenvolvimento e cooperação internacional: a solidariedade alemã com base na realidade brasileira. Espaço Acadêmico. São Paulo, 2010. Disponível em: http://www.espacoacademico.com.br/033/33andrioli.htm. Acesso em: 05 fev. 2010.

12 "A busca desenfreada pela industrialização e pelo desenvolvimento econômico levou a maioria dos países do mundo a concentrar seus esforços na promoção do crescimento do Produto Interno Bruto (PIB), deixando a qualidade de vida em segundo plano. O crescimento econômico era visto como meio e fim do desenvolvimento. Essa visão está mudando lentamente, mas deixou graves danos para a humanidade". Trecho da Revista da FAE. Uma discussão sobre o conceito de desenvolvimento. (Gilson Batista de Oliveira, 2002, pg.39)

${ }^{13}$ O conceito de "país desenvolvido" é utilizado para descrever os países que têm alto nível de desenvolvimento econômico e social, tomando como base alguns critérios. Critérios econômicos têm vindo a dominar as discussões. Um desses é a renda per capita e o valor do produto interno bruto per capita de cada país. Outro critério econômico é a industrialização. Os países onde os setores terciário e quaternário da indústria predominam na economia são considerados desenvolvidos. Mais recentemente uma outra medida, o Índice de Desenvolvimento Humano (IDH), começou a ser utilizada.

${ }^{14} \mathrm{O}$ IDH mede três dimensões: riqueza, educação e expectativa média de vida e é uma maneira padronizada de avaliação e medida do bem-estar de uma determinada população. Os países "desenvolvidos" geralmente são os que apresentam IDH elevado. Países que não entram em tais definições são classificados como países em desenvolvimento.
} 
outro referencial, o Índice de Pobreza Humana (IPH). Esses foram importantes nos estudos comparativos e de planejamento de políticas contra a pobreza. Em torno do conceito de IDH e IPH formou-se o entendimento de que o desenvolvimento está relacionado à melhoria da qualidade de vida de um povo. Idéias como a de democracia e a de desenvolvimento são regulativas. Sua concretização leva a população a alcançar maiores níveis de humanização. Essa compreensão concorda com a concepção de desenvolvimento dos países da União Europa e objetiva a emancipação dos seres humanos, a mudança das estruturas de desigualdade, de injustiça e de alienação que os impedem de decidir livremente, no amplo sentido do termo. Com isso fica evidente a necessidade de transformações tanto no nível das ações dos países industrializados em direção aos países "em desenvolvimento" quanto desses em direção aos primeiros. A unilateralidade nas relações da assim chamada ajuda ao desenvolvimento precisa ser superada mutuamente com intercâmbios bi ou multilaterais.

Sendo assim, a organização de uma cooperação em redes de intercâmbio mútuo, pelo receptor ou pelo atuante, é fundamental. Experiências internas dos países realizadores, como mobilização contra o desmonte social na Alemanha, também podem contribuir e trazer conhecimento aos povos dos países "em desenvolvidos". As ações que procuram atingir o núcleo da injustiça no mundo precisam ser implementadas em caráter internacional - contra a dominação do capital financeiro; contra o pagamento da dívida externa; a favor da segurança alimentar e contra a concentração no setor alimentar -, por meio de modificações no consumo e da influência sobre a política internacional. Assim estaremos colaborando para a afirmação dos direitos humanos ao fortalecimento da cooperação e da solidariedade internacional.

Nas relações de cooperação internacional, é importante que sejam preservados os princípios da igualdade e da solidariedade para impedir que se repitam as estruturas de dependência, típicas no diálogo entre norte e sul. A cooperação é, em última instância, um intercâmbio com o qual ambos os lados aprendem. Ao longo do século 21, noções como "deterioração dos termos de troca" (Hans Singer, Raul Prebish); pólos de desenvolvimento (Francois Perroux); "teoria da dependência" (Fernando Henrique Cardoso); "subdesenvolvimento estrutural (Celso Furtado), "ecodesenvolvimento" (Ignacy Sachs), entre outras, foram utilizadas para interpretar a 
complexidade da realidade dos países em vias de desenvolvimento e apresentar recomendações políticas.

O conceito de "parceria para o desenvolvimento", adotado pela política externa brasileira durante o governo do presidente Luís Inácio Lula da Silva, consolida a idéia de que a relação de cooperação conduz os lados participantes a compartilhar esforços e benefícios. As propostas são avaliadas à luz do impacto e do alcance sobre as comunidades receptoras, procedimento que demanda o aprimoramento dos mecanismos de negociação, de avaliação e de gestão dos projetos, a fim de enquadrálos às prioridades nacionais.

Por isso é importante agir e pensar localmente, pois as necessidades das pessoas precisam ser supridas lá onde elas vivem. Também porque a problemática fica mais evidente em nível local e é especialmente partilhada pelos especialistas locais. O sucesso da cooperação só é possível com a participação do quadro de trabalhadores e especialistas da região e com o envolvimento dos locais e dos cooperantes no processo de desenvolvimento.

Dentro dos projetos implementados nos países "em desenvolvimento", o desenvolvimento deve ser entendido como um processo endógeno, no qual a forma como se concebe a construção do conhecimento é um elemento importante. Segundo o constatado pelo educador brasileiro Paulo Freire, a transferência ou transmissão de conhecimento não é possível, pois, ou se trata de apropriação do conhecimento, ou haverá um processo de dominação em curso. O apoio internacional na área do conhecimento é, no entanto, importante para a formação de saberes competentes e a geração de tecnologias apropriadas. Além disso, a cooperação internacional dá ânimo às organizações e pode contribuir para que mais pessoas sejam capacitadas a participar de decisões que afetam suas próprias necessidades.

Para concluir, é importante reforçar que, com exceção das diferenças culturais, sociais e políticas, há interesses comuns e necessidades de mudança em todo o mundo, o que evidencia que a própria cooperação internacional ao desenvolvimento é um processo educativo, no qual concepções, objetivos e visões são modificadas mutuamente. $\mathrm{O}$ Fórum Social Mundial desde sua fundação em Porto Alegre, demonstrou a 
importância de preservar e respeitar a diversidade na organização em rede de cooperações e, apesar disso, apontar objetivos comuns. Na política internacional de apoio ao desenvolvimento, também parece ser muito importante que se constitua uma rede internacional com diferentes organizações cujos objetivos são os mesmos, de maneira que a ação global e local seja alcançada. Para isso, o mútuo diálogo entre organizações parceiras do norte e do sul não deveria ser somente um meio de fortalecimento da cooperação, mas a base para a formulação das concepções, dos objetivos, dos métodos e das visões de desenvolvimento de um todo.

\subsection{Histórico da cooperação em desenvolvimento}

$\mathrm{O}$ processo de intercâmbio entre países, que marcou o desenvolvimento do capitalismo desde o período mercantil dos séculos 17 e 18, expande-se com a industrialização, ganha novas bases com a grande indústria, nos fins do século 19, e, agora, adquire mais intensidade, mais amplitude e novas feições. O mundo inteiro torna-se envolvido em todo tipo de troca: técnica, comercial, financeira, cultural. ${ }^{15}$

As formas de Cooperações para o Desenvolvimento variaram ao longo da história como reflexo da evolução não somente das teorias e dos modelos de desenvolvimento, como também da própria conjuntura geopolítica internacional.

O Plano Marshall foi, em 1947, o grande marco da Cooperação para o Desenvolvimento. Criado pelos Estados Unidos (EUA), o plano foi destinado a ajudar a reconstruir a Europa, que se encontrava financeiramente arrasada depois da guerra, com sua população, suas cidades e indústrias devastadas. Trata-se da primeira idéia de cooperação financeira e também do primeiro projeto específico de Cooperação para o Desenvolvimento. Para coordenar as atividades associadas aos recursos monetários, foram criadas várias instituições que se tornaram determinantes e diretivas no campo da Cooperação para o Desenvolvimento. A principal foi a Organização para a Cooperação Econômica Européia (OECE), fundada em 1948, e direcionada inicialmente, como o próprio nome indica, a apoiar o continente europeu. Mais tarde, a organização expandiria suas atividades para outros continentes, quando foi

\footnotetext{
${ }^{15}$ Santos, Milton. Por uma globalização mais humana. Editora Folha de São Paulo. São Paulo, 2001.
} 
reformulada, em 1968, e passou a ser chamada de Organização para a Cooperação e Desenvolvimento Econômico (OECD). Ela encontra-se até hoje em vigência. Há quatro décadas, o pensamento sobre o crescimento e desenvolvimento era influenciado por teorias de crescimento econômico keynesianas ${ }^{16}$ e teorias de modernização. Ambas consistem no postulado de que o Estado deve intervir no desenvolvimento de um país, criando as condições para que o capital produzido no ali contribua para seu o desenvolvimento. De acordo com essa premissa, o desenvolvimento decorre da transição de uma cultura tradicional para uma "cultura moderna" ou industrializada. Argumentava-se que, desde que houvesse injeção de capital no país e principalmente na sua economia, o Estado seria capaz de regularizar a situação do seu país. Essa estabilização gerada por meio dos recursos financeiros criaria condições para que a acumulação de capital fosse possível para esse país, que teria garantida a sua transição para uma sociedade industrializada ou para uma "sociedade modernizada e desenvolvida", para usar os termos das teorias keynesianas. A solução para o país seria então: "Se um estado não tiver capital e necessitar de ajuda, basta injetar capital no país e a situação se resolverá". ${ }^{17}$

O rápido crescimento dos países europeus ajudados pelo Plano Marshall demonstrou o sucesso da ação norte-americana. Após a Segunda Guerra Mundial, e em decorrência da fragilidade dos países colonizadores, iniciou-se um vasto processo de descolonização, durante o qual vários territórios pertencentes a potências européias lograram independência. Esses processos de independência aceleraram a implementação da recém-criada Cooperação para o Desenvolvimento, privilegiando ações que partiram das potências colonizadoras e em direção às suas ex-colônias. $\mathrm{O}$ sucesso do Plano Marshall criou a expectativa de que era possível conseguir os mesmos progressos rápidos nos países em desenvolvimento, principalmente na África e na Ásia, como defendia a Comissão Pearson". Os países "desenvolvidos"

\footnotetext{
${ }^{16} \mathrm{~A}$ escola keynesiana se fundamenta no princípio de que o ciclo econômico não é auto-regulador como pensavam os neoclássicos, uma vez que é determinado pelo "espírito animal" dos empresários. É por esse motivo, e pela ineficiência do sistema capitalista em empregar todos que querem trabalhar que Keynes defende a intervenção do Estado na economia.

${ }^{17}$ Afonso, Maria Manuela. Cooperação para o desenvolviemto: o papel da ajuda no contexto africano. Universidade de Sao Paulo. Brasil, 2005. Pag.41

${ }^{18}$ A Comissão Pearson objetivava lançar uma ajuda internacional, em termos principalmente de recursos financeiros, para Ásia e para a África. Pensava assim que se estaria colaborando para o crescimento da economia dos países desses continentes, já que a escassez de capital era vista como a principal barreira para o desenvolvimento. Essa ajuda, no entanto, foi usada como instrumento de
} 
canalizariam 1\% do seu Produto Nacional Bruto (PNB) para ajudar esses continentes, agregando à essa porcentagem todo o tipo de recursos financeiros, públicos e privados. De acordo com as estimativas (comprovadas nos países europeus quando aplicado o Plano Marshall), tais recursos provocariam fariam os países atingirem uma taxa de crescimento anual de 6\%. Essa meta, contudo, nunca foi alcançada.

A seleção dos países a apoiar, para além do relacionamento entre ex-colonizador e colônia, fez-se sobretudo com base em considerações geoestratégicas dos blocos ocidentais (os capitalistas) e blocos orientais (os soviéticos), procurando-se que os países receptores da ajuda não passassem para "o outro lado", o lado do comunismosoviético. Tendo em mente as teorias keynesianas de crescimento e as teorias de modernização, visou-se ajudar as economias emprestando e investindo capital nos Estados recém-formados, com a esperança de que encontrar o mesmo sucesso obtido na reconstrução da Europa. Mas nesse caso não se passou o mesmo. "A razão pela qual se pensava que isso aconteceu foi a fraca modernização dos países subdesenvolvidos". ${ }^{19}$

A ajuda (APD) era vista como fundamental para planejar o desenvolvimento, devendo centrar-se nos setores considerados motores da industrialização, a fim de que fosse evitado simultaneamente o problema do endividamento. Entre os anos 70 e 1982, a APD, no entanto, se situou apenas nos 0,30 a $0,35 \%$ do PNB dos países doadores, quando o objetivo estabelecido era inicialmente $0,70 \%$.

Embora a meta nunca tenha sido alcançada, até aos anos 90 a APD foi o fluxo externo mais importante na promoção do desenvolvimento ${ }^{20}$. Na primeira fase da cooperação, entre os recursos privados, o Investimento Direto Estrangeiro (IDE) não era bem visto, dado ser associado a formas de ingerência e neo-colonialismo, particularmente no que se refere às grandes empresas multinacionais. Quanto aos empréstimos bancários, eles aumentaram significativamente nos anos 1970 em razão dos petrodólares. A alta do petróleo possibilitava aos países vendedores dessa matériaprima, como os países da Organização dos Países Exportadores de Petróleo (OPEP),

\footnotetext{
política externa para manter as alianças e a presença estrangeira nas suas economias.

${ }^{19}$ Afonso, Maria Manuela. Cooperação para o desenvolviemto: o papel da ajuda no contexto africano. Universidade de Sao Paulo. Brasil, 2005. Pag. 49

${ }^{20}$ Ibidem
} 
uma grande disposição de capital, os chamados petrodólares, que foram destinados à projetos ou à concessão de empréstimos.

Com o não êxito da cooperação nos países em desenvolvimento e em razão da grande disposição de capital pela alta do petróleo, passou-se a apoiar projetos de industrialização, construindo-se infra-estruturas modernas nos países "subdesenvolvidos" nas áreas de saúde, da indústria, da agricultura, da educação, etc. O fato foi designado de "paradigma dos projetos setoriais", visto que consiste em apoiar diretamente projetos de vários setores econômicos e sociais.

Os investimentos de capitais privados não produziram, porém, resultados sustentáveis no plano do desenvolvimento. Esqueceu-se de levar em consideração a realidade dos países onde foram aplicados o capital. A instalação de modernas estruturas não foi acompanhada por um debate sobre sua utilidade e sobre a forma como essas deveriam estar integradas à rotina e à melhoria da vida da população desses países. Com a deterioração dos termos de troca, as receitas das exportações induzidas pelos investimentos diminuíram e, conseqüentemente as despesas governamentais correntes aumentaram. Esses fatos, conjugados com a crise petrolífera e com a subida das taxas de juros - atingindo principalmente os empréstimos por meio da grande disposição de petrodólares -, conduziram à emergência da crise da dívida no mundo em desenvolvimento, ficando os anos 1980 marcados pelo esgotamento dos financiamentos privados, pelo "fracasso do desenvolvimento" e pelos questionamentos dos modelos e estratégias de desenvolvimento adotadas até então.

Assim se esgotaram os paradigmas que serviram às relações norte-sul na última metade do século 20. As motivações se devem, em boa medida, à rigidez filosófica, ideológica e mesmo operacional dessas relações que não souberam se atualizar de maneira a atender às novas realidades nacionais, regionais e globais. A progressiva perda de substância do modelo anterior - que se reflete de forma dramática na diminuição dos recursos alocados pelos doadores tradicionais - se, por um lado, não coincidiu com o surgimento de outro modelo, por outro provoca um debate estimulante sobre o futuro da cooperação internacional ao desenvolvimento.

Independentemente da motivação inovadora que ensejou a criação de mecanismos 
específicos para a promoção da CID tanto no âmbito bilateral como multilateral, por aproximadamente três décadas essa atividade não deixou de refletir as realidades políticas e econômicas do sistema internacional. De um lado, promoveu-se o conceito de assistência técnica para a superação do subdesenvolvimento, a partir de um ponto de vista fundamentalmente econômico/produtivo. Paralelamente, os programas e projetos estruturavam-se a partir de uma estreita relação norte-sul (ou "país desenvolvido" para "país em desenvolvimento" e ainda "país com recursos financeiros e humanos" para "país sem recursos financeiros e humanos").

$\mathrm{O}$ cenário internacional começou a alterar-se substantivamente. $\mathrm{O}$ crescimento econômico dos países em desenvolvimento e o fortalecimento de suas capacidades internas nesse período - progressos que contaram em diversos momentos com a CID como ferramenta essencial - acarretaram profundo impacto sobre a cooperação técnica, com a revisão de sua conceitualização e dos mecanismos de implementação dos projetos.

O início dos anos 1990 foi marcado por uma profunda mudança do modelo de financiamento do desenvolvimento, podendo identificar-se as seguintes tendências: o IDE a crescer de forma regular, com urna expansão rápida e sustentável no final da década e a APD a diminuir, quer em termos nominais, quer em \% do PNB dos países doadores, situando-se nos 0,39\% do PNB em 1999.

Pela primeira vez na história da cooperação, e em conseqüência da conjugação de uma série de fatores (entre os quais se destacam as novas abordagens do desenvolvimento e o papel da cooperação nesse processo), as mudanças geopolíticas pós-guerra fria, a recessão econômica nos países da OCDE, os recursos privados e, em particular, o IDE tornaram-se as principais fontes de financiamento do mundo em desenvolvimento e a Ajuda tornou-se um componente minoritário. Novas abordagens foram concebidas e implantadas visando o aperfeiçoamento da cooperação.

De fato, hoje observamos um embate entre aqueles que defendem o sistema antigo paternalista e assistencialista - e aqueles que ousam propor formas inovadoras e mais 
eficientes de se atingir os objetivos mais nobres da cooperação. ${ }^{21}$

No presente cenário internacional, não é mais possível aplicar os critérios tradicionais para definir a natureza e os objetivos da $\operatorname{CID}^{22}$. A reflexão sobre a questão de realidades complexas nos países cooperados é de maior relevância, pois existem implicações não apenas operacionais, mas também políticas. Para balizar essa reflexão, cabe observar o presente contexto internacional:

- Muitos países em desenvolvimento contam hoje com economias diversificadas e grande capacidade de produção de bens e serviços;

- Esses mesmos países possuem recursos humanos capacitados em instituições de elevada qualidade técnica e atualmente os programas de cooperação técnica não se resumem mais à transferência de conhecimento e tecnologia, assumindo contornos mais amplos. Com isso a busca de impactos no desenvolvimento dos países em transformação passou de objetivo de longo prazo para meta imediata.

É cada vez mais comum que projetos para o desenvolvimento cumpram o papel de mediadores entre Governo, sociedade civil (as ONGs) e o setor produtivo do país. Há uma crescente preocupação, no âmbito dos países "em desenvolvimento", com relação à melhoria das estruturas administrativas, dada a necessidade de otimização dos recursos públicos, a cooperação de Good Governance. Esse tipo de cooperação tem colaborado para o combate à corrupção e à burocracia, duas grandes barreiras ao desenvolvimento do país. A luta contra a corrupção e a burocracia é essencial quando se trata de promover a transparência nas políticas públicas e a melhoria do uso do recurso público nos países em desenvolvimento.

\footnotetext{
${ }^{21}$ Discurso de Marco César Meira Naslausky. Cooperação técnica entre países em desenvolvimento: tendências e perspectivas. XV Reunião de Diretores de Cooperação Internacional da América Latina e do Caribe 11 a 13 de março de 2002, Montevidéu, Uruguai. Disponível em: http://www.sela.org/public html/AA2K2/ESP/docs/Coop/spxvrdcialcdi8-02/spxvrdcialcdi8-1.htm. Acesso em: 01 fev. 2010.

${ }^{22}$ Ibidem.
} 
Atualmente, observa-se também um forte processo de descentralização da ação Estatal na implementação das cooperações. Concomitante ao aperfeiçoamento dos meios de comunicação e aos reflexos imediatos sobre o planejamento e a gestão dos projetos de Cooperação Técnica, verifica-se crescente consenso, em nível nacional e internacional, sobre a necessidade de se buscar sinergias entre as diferentes vertentes da cooperação internacional para o desenvolvimento, historicamente ausentes por uma série de circunstâncias. Novas modalidades de cooperação conquistaram, por isso, seu espaço, como foi o caso da Cooperação Sul-Sul ${ }^{23}$. A integração dos países em desenvolvimento com a economia mundial e também entre eles mesmos, como é o caso de diferentes blocos econômicos que surgiram logo depois da fundação da União Européia, passa agora a ser considerada um componente incontornável no processo de desenvolvimento dos países emergentes, como veremos no âmbito dos países do Mercosul.

Penso, portanto, que durante o século 21, a cooperação entre os país do hemisfério sul está crescendo e pode se tornar um dos principais itens da agenda diplomática bilateral dos países em desenvolvimento. O que consideramos aqui uma tendência começou a ser percebida mais claramente nos últimos anos da década de 1990.

A cooperação Sul-Sul oferece potencialidades para o estreitamento das relações internacionais entre países em desenvolvimento. O crescimento do seu poder de lobby a nível internacional tem sido objeto de atenção de parte dos governos desses países. O trabalho desenvolvido pelas instituições que atuam na promoção da cooperação entre países em desenvolvimento tem superado as expectativas iniciais e respondem, hoje, por uma parte substantiva dos programas mantidos nos países emergentes, os quais tampouco querem substituir a cooperação vertical. Do contrário, demonstram querer complementá-las, redimensioná-las e enriquecê-las.

\footnotetext{
${ }^{23}$ A cooperação "Sul-Sul' também chamada de cooperação horizontal, pois acontece no âmbito do hemisfério Sul para o Sul, ou seja, de forma horizontal. Esse tipo de cooperação oferece o estreitamento das relações internacionais mantidas entre os países em desenvolvimento, praticamente em todas as áreas do conhecimento, tem sido objeto de crescente atenção por parte dos Governos dos mencionados países.
} 


\subsection{A União Européia e a Cooperação Técnica Internacional}

A União Européia é a maior financiadora da cooperação para o desenvolvimento da América Latina e Caribe (ALC), e tem destinado, desde 2007 e até 2013, um total de 2,69 bilhões de euros para a realização de programas de cooperação na região. Os principais objetivos europeus com as cooperações nos países latinos emergentes são, essencialmente, a promoção da coesão social e da integração regional, além da promoção de temas relacionados com a boa governança, o ensino superior e o desenvolvimento sustentável. Seus projetos de cooperação vêm sendo implementados em 17 países da região e em mais três grupos regionais (Mercosul, Comunidade Andina e América Central), sendo que os programas funcionam de modo transfronteiriço. Os maiores programas de desenvolvimento com a América Latina são Euro Social (promoção da coesão social), UrbAl (promoção da cooperação a nível local), AL-Invest (promoção da competitividade internacional do AL-PME), Alpha III (modernização dos sistemas de ensino superior), Erasmus Mundus (bolsas)e @ LIS (integração da AL na sociedade da informação global).

Não é fácil separar as linhas e os objetivos da Cooperação para Desenvolvimento da União Européia e da República Federativa da Alemanha. A Alemanha, por ser um dos países fundadores desse bloco, desenvolveu ali muitos dos seus tópicos políticos, econômicos e principalmente sociais. Esse fato se reflete nas similaridades dos seus projetos e nas prioridades a serem alcançadas com a Cooperação para o Desenvolvimento.

A “parceria estratégica” entre a União Européia (UE) e a ALC (América Latina e Caribe) comemorou 10 anos em 2009. Os dois blocos se deram às mãos em junho de 1999 na primeira cimeira UE-ALC, realizada no Rio de Janeiro. A parceria tem como base o patrimônio cultural comum, herança da imigração, e os valores ocidentais compartilhados, que contribuem para uma estreita cooperação nos domínios político, econômico, cultural e científico-tecnológico.

A parceria bi-regional foi sendo desenvolvida e aperfeiçoada ao longo de quatro outras cúpulas (Madri 2002, Guadalajara 2004, Viena 2006, Lima 2008). Essas cimeiras tornaram-se uma plataforma de diálogo político sobre as questões globais 
importantes e serviram para dar impulso aos projetos específicos no âmbito das relações regionais (associações, parcerias, direcionamento da cooperação para o desenvolvimento etc.) A parceria bi-regional da União Européia com a ALC consiste em uma densa rede de relações variadas, atividades e mecanismos de cooperação também em nível governamental. Ela apresenta um vasto espectro de eventos que não se reduzem somente às cimeiras entre os continentes a cada dois anos, mas também a reuniões de ministros das Relações Exteriores da UE-Grupo do Rio, reuniões periódicas de altos funcionários e reuniões com a participação da sociedade civil, parlamentos e empresários.

A próxima cúpula dos chefes de Estado e Governo será realizada ainda neste ano de 2010, em Madri, sob a direção da presidência espanhola na União Européia. A data prevista para o encontro é 18 de maio. Essa reunião terá como foco temático o campo da ciência e da inovação.

A Alemanha contribui ativamente estimular o quadro da cooperação entre UE-ALC e tem realizado uma série de eventos técnicos em diferentes temas pertinentes, à exemplo o seminário de Peritos sobre Armas de Pequeno Calibre (2007), a política fiscal UE-ALC (março de 2008 e maio de 2009, em Berlim), a organização de seminários em Montevidéu e um fórum UE-ALC sobre Responsabilidade Social em 2008 e 2009, em Buenos Aires. Em abril deste ano será realizado ainda um importante encontro sobre a política energética em Berlim (dias 29 e 30).

A estratégia e o direcionamento da Cooperação para o Desenvolvimento da União Européia com a ALC foi reeditada em 30 de setembro de 2009. A Comissão Européia divulgou um documento intitulado em "A União Européia e América Latina: atores globais no âmbito da parceria". O título desse novo documento reflete o atual contexto que cerca os novos conceitos de Cooperação para o Desenvolvimento em países emergentes. A partir desse documento, novos tópicos são abertos e alguns reafirmados: a intensificação e a orientação do diálogo bi-regional, o fortalecimento da integração regional e sua interconexão, o fortalecimento das relações bilaterais e uma maior atenção às diferentes circunstâncias, a reorientação e adaptação dos novos e antigos programas de cooperação e a promoção de um novo instrumento para o desenvolvimento da inter-conectividade, da integração regional e da coesão social. 
Outro tópico de discussão são as doações e a porcentagem APD por país. O compromisso inicial de aportar $0,7 \%$ do PIB para a cooperação ao desenvolvimento ainda não foi ainda cumprido. Somente cinco países cumprem hoje essa meta, e entre eles está a Alemanha.

\subsubsection{A Cooperação de Desenvolvimento na Alemanha}

O Governo Federal na Alemanha é um dos maiores financiadores de cooperação para o desenvolvimento do mundo e de acordo com o site do Ministério para Cooperação Econômica e de Desenvolvimento (Bundesministerium für wirtschaftliche Zusammenarbeit und Entwicklung - BMZ), o maior financiador na região da América Latina e Caribe.

\subsubsection{Temas e princípios}

Os princípios estabelecidos no programa de cooperação alemão seguem o direcionamento de uma política de desenvolvimento que busca combater a pobreza global, garantir a paz, alcançar a democracia, promover uma globalização justa e proteger o meio ambiente. Segundo seus documentos oficiais, sua política de cooperação é baseada na visão de um desenvolvimento global sustentável, que na mesma velocidade promova de forma justa o desenvolvimento econômico e social dos países emergentes, contribua para um meio ambiental sustentável e promova a estabilidade política dos países cooperantes.

Seu governo apóia ativamente o início de uma nova parceria global entre os países “desenvolvidos" e em transformação. Os princípios da gestão de desenvolvimento da política alemã estão baseados na Declaração do Milênio das Nações Unidas e seus Objetivos de Desenvolvimento para o futuro - tendo também em conta o consenso da Conferência de Financiamento do Desenvolvimento em Monterrey (mais conhecido como Consenso de Monterrey), e o Plano de Ação da Cúpula Mundial de 
Sustentabilidade em Johanesburgo - junto com os compromissos assumidos na Declaração de Paris sobre a eficácia da estrutura dos programas de desenvolvimento, o cumprimento da $\mathrm{ODA}^{24}$ (Official Assistance Development), Agenda AidEffectiveness e o "acordo de coligação" 25 . Este último documento é a mais importante vertente do programa alemão e foi redigido e assinado entre os partidos de maioria no atual governo, Partido Democrático Cristão- CDU, Partido União Social Crista- CSU e Partido Democrático Livre- FDP.

As prioridades do seu programa governamental incluem áreas temáticas, setores ou sub-setores que serão expostos por meio de projetos, programas regionais ou programas comunitários. Eles estão interligados por um conceito abrangente ou uma estratégia de contribuição significativa e para a resolução dos problemas estruturais do país parceiro do núcleo.

Os temas e tópicos mais desenvolvidos dentro da cooperação alemã para o desenvolvimento são:

- Democracia, sociedade civil e administração pública (incluindo os direitos humanos, incluindo de mulheres e de crianças, a reforma judicial, a descentralização e desenvolvimento local);

- Construção da paz e medidas preventivas contra crises ou conflitos (incluindo os esforços para a paz e para a reconciliação);

- Educação;

- Saúde, planejamento familiar e a luta contra a epidemia da AIDS;

24 ODA em português: Assistência Oficial ao Desenvolvimento. Os países membros do Comitê de Desenvolvimento da OCDE disponibilizam, diretamente ou por meio de organizações internacionais, recursos para projetos. O Conselho Europeu decidiu em junho de 2005 que até 2015 iria aumentar a ODA da União Européia para $0,7 \%$ do total de seu PIB.

${ }^{25}$ No acordo de coligação do FDP, CDU e CSU assinado em outubro de 2009, o governo federal alemão se compromete com as metas de desenvolvimento internacional e deseja acabar com a pobreza e com as deficiências estruturais dentro da concepção da Declaração do Milênio das Nações Unidas. Os elementos centrais da política de desenvolvimento alemão são o reforço à boa governança e à participação. O setores chave da cooperação para o desenvolvimento definidos no acordo de coligação são as áreas da boa governança, da educação, da saúde, do desenvolvimento rural, do clima, do ambiente e da proteção dos recursos naturais e da cooperação econômica. 
- Água potável, gestão da água, sistema de saneamento e esgotos;

- Segurança alimentar e agricultura (incluindo a pesca);

- Meio Ambiente, proteção e uso sustentável dos recursos naturais (incluindo a luta contra a desertificação, a conservação da fertilidade do solo, manejo florestal sustentável e biodiversidade);

- Desenvolvimento econômico sustentável (a promoção do sector privado, o desenvolvimento dos sistemas financeiros, formação e mercado de trabalho);

- Energia (incluindo a eficiência energética, energias regenerativas e renováveis);

- Transportes e comunicações estruturais.

\subsubsection{Objetivos}

A cooperação ao desenvolvimento deve, de acordo com o governo alemão, oferecer às pessoas liberdade para que não tenham dificuldades materiais e possam ter a responsabilidade pelas suas vidas. Nesse sentido, o governo alemão pretende contribuir por meio da sua política de desenvolvimento assegurar que a globalização ofereça oportunidades iguais para todos.

Atualmente, a cooperação alemã para o desenvolvimento concentra-se nos setores da educação, saúde, desenvolvimento rural, a boa governança e o desenvolvimento econômico sustentável, tendo como princípio orientador a proteção dos direitos humanos.

A base para a ação do governo federal processa-se a partir do acordo de coligação. Existem seis prioridades para a Cooperação e Desenvolvimento Alemão:

1. Combater a pobreza de forma sustentável

O objetivo da política internacional alemã de desenvolvimento é alcançar os "Objetivos de Desenvolvimento do Milênio", que incidem principalmente sobre a 
redução da pobreza. Para o governo federal alemão, está atrelado à luta contra pobreza educacional, dada a importância desta última para a formação de cidadãos conscientes de seus próprios direitos.

\section{Reduzir os déficits estruturais}

Nos países parceiros da cooperação alemã e nas estruturas da comunidade internacional, o governo federal quer promover a boa governança. Para isso, ele deve acionar, entre outras coisas, a eliminação dos subsídios às exportações agrícolas, que desde 2001 encontra-se em curso nas negociações OMC que concluirá a Rodada de Doha.

\section{Reforçar o diálogo com a sociedade civil}

Dois dos principais temas da agenda de cooperação alemã são uma ativa participação da sociedade civil e o aumento da sua influência nas decisões políticas e na descentralização da concentração do poder. De acordo com o Ponto de vista governamental, a cooperação tem sido e deverá futuramente ser apoiar e promover, tanto nos países parceiros como também na Alemanha, o respeito ao desejo da maioria da população e implementação dos seus desejos por partes dos governantes, quais foram democraticamente escolhidos. Fortalecer a democracia com uma participação igualitária para todos é primado do direito, principalmente o envolvimento nas tomadas políticas da sociedade civil organizada e, em especial, a participação da parte população sem recurso.

A cooperação alemã exerce uma função de observador e consultor, que fiscaliza, debate o tema e reforça o direito de participação dos cidadãos nas decisões do seu Estado diante dos governos. Ela também serve como fiscal da ação do Estado frente ao cidadão, para que não haja abuso de poder e tampouco o desrespeito dos direitos da população. Sua função é promover uma participação política mais ativa (incluindo os direitos das mulheres e dos direitos dos povos indígenas) e desenvolver o conceito de boa governança na área das políticas e finanças públicas. Este tópico é o tema mais promovido no âmbito do Mercosul.

4. Reforçar o compromisso do desenvolvimento econômico 
Não há desenvolvimento sustentável sem desenvolvimento econômico sustentável. O governo alemão continua reforçando o compromisso com economia dos países "em desenvolvimento". A continuação do seu programa de cooperação a longo prazo tem como objetivo promover uma melhor infra-estrutura social e econômica, uma expansão no setores produtivos e uma reforma do sector financeiro. O governo alemão na sua cooperação para o desenvolvimento continuará, entre outras medidas, a promover socialmente e de forma responsável a governança corporativa (responsabilidade social das corporações) e ampliar as parcerias para o desenvolvimento com o setor privado (Parcerias Público-Privadas).

Um instrumento particularmente importante neste tópico do programa governamental alemão é a promoção de micro-créditos, recursos imprescindíveis na ajuda de desenvolvimento de uma população. Os programas de micro-créditos são direcionados principalmente a agricultores e a população rural. A cooperação cumpre assim umas das suas principais missões, que é promover o co-investimento a os parceiros da cooperação, fornecendo recursos financeiros e medidas complementares para sua eficiência e melhor desenvolvimento financeiro do país em transformação.

Um outro tópico discutido pela agência de cooperações alemãs é como poderá haver um melhor aproveitamento da economia local por meio de investimentos. O governo alemão aposta que o êxito de uma cooperação no âmbito econômico está no investimento em ativos fixos, imóveis, bens e equipamentos, na participação e em empréstimos às empresas dos países parceiros, na prioridade de contribuir capital para financiar medidas de desenvolvimento sustentável (por exemplo, as medidas de conservação) e também medidas macroeconômicas (como por exemplo, Poverty Reduction Support Credit - PRSC). Esse tipo de financiamento tem grande importância no objetivo de obter mudanças estruturais e de criar estruturas mais eficientes nos países parceiros.

5. Reforçar a eficiência de seu programa de cooperação ao desenvolvimento

A Alemanha vê o acompanhamento da eficiência de sua cooperação como ponto importante a ser implementado, o qual foi destacado na Declaração de Paris e na Agenda de Ação de Accra. 
É com a intenção de intensificar sua cooperação que o governo alemão planeja, por meio de reformas organizacionais e estruturais, aumentar a eficácia de sua política para o desenvolvimento. Ele vem trabalhando, por isso, com a reforma de suas agências cooperadoras, a GTZ, a DED e a InWent, que as levará a serem uma única organização conjunta e interligada, destinada à cooperação técnica. O governo federal acredita também que a manutenção da diversidade em todos os setores de suas cooperações é um fator decisivo para aumentar a eficácia de sua parceria e alcançar um maior espectro de cooperantes.

\section{Melhorar a sua visibilidade e transparência}

Para o governo alemão, uma cooperação bem sucedida requer um maior apoio e uma participação dos cidadãos. Para isso, o BMZ está reforçando a promoção de um trabalho de cooperação mais informativo e educacional para que obtenha uma maior comunicação com a população que vem sendo afetada pela cooperação. Em cada programa são atribuídos metas e indicadores de impacto, como forma de controle de aplicação dos recursos e transparência diante dos países doadores.

Para implementar esses objetivos, exercer suas crescentes funções destacadas nos documentos acima citados e lançar novos desafios, o governo alemão lançou o Plano de Ação 2015. Seu objetivo central é aumentar as contribuições para a redução da pobreza (como foi expressado no Poverty Reduction Strategy Papers - PRSP). Essas contribuições vêm sendo mobilizadas pelo governo federal alemão em nível internacional, mas chegam também através da colaboração de outros países parceiros e em conjunto com estratégias de sustentabilidade nacional realizadas junto com o país receptor.

De acordo com seus documentos oficiais, o governo alemão expõe as políticas de desenvolvimento considerando-as como um problema da comunidade internacional. Ele molda e projeta seu trabalho como um bloco de construção de uma política estrutural e global da paz $^{26}$. E espera que com a cooperação ele também apóie os países em desenvolvimento na melhoria de suas condições internas e estruturais.

\footnotetext{
${ }^{26}$ Bundesministerium für Wirtschaft und Zusammenarbeit. BMZ Materialien 183. Informationsmappe Lateinamerika. Die entwicklungspolitische Zusammenarbeit Deutschlands mit Lateinamerika und der Karibik. Bonn, dezembro de 2007
} 
Seu trabalho processa-se em especial no âmbito dos acordos bilaterais, multilaterais e da cooperação da UE para o desenvolvimento, sendo os países cooperantes adequadamente envolvidos no processo de negociação de suas transformações estruturais e adequados aos princípios ocidentais dos regimes democráticos internacionais.

\subsubsection{Meios e atores}

O ator mais importante na política de cooperação na Alemanha é o Ministério Federal para Cooperação Econômica e para Desenvolvimento (BMZ). Sua função é ser agir um coordenador geral dos programas e dos projetos de cooperações. Ele administra os recursos financeiros públicos e distribui-os para as agências de cooperações, que serão abaixo apresentadas. Cerca de $80 \%$ do seu quadro de funcionários e de seções está na sede oficial em Bonn e a outra parte em seu escritório em Berlim. O Ministério, mesmo depois da união das "duas Alemanhas", continua com sua sede em Bonn, antiga capital da República Federal da Alemanha. Parte de seu quadro de trabalhadores sai regularmente há vários anos, a fim de que Ministério seja mais ativo para o desenvolvimento em nível mundial. Em sistema de rodízio entre Alemanha e exterior, cerca de 10\% dos empregados trabalham em missões estrangeiras da República Federal da Alemanha em organizações internacionais ou em projetos de desenvolvimento específicos.

O BMZ é encarregado da execução dos projetos e conhecido como o mecanismo e o organismo de execução de trabalhos em conjunto com os promotores, que são determinados pelo governo do país parceiro.

Os corpos de execução do governo alemão incluem o Serviço Alemão de Desenvolvimento (DED), Coorporativa Alemã de Investimento e de Desenvolvimento (DEG), a Agência Alemã de Cooperação Técnica (GTZ), Banco de Desenvolvimento KFW, Empresa Internacional de Formação e Desenvolvimento gGmbH (InWent) e Centro de Migração Internacional e Desenvolvimento (CIM). 
As organizações estaduais colocam em prática e desenvolvem os projetos do governo alemão. Elas seguem integralmente as instruções do BMZ, porém têm sua própria coordenação e sua própria equipe de colaboradores para a cooperação.

Diversos organismos desenvolvem o trabalho de cooperação entre a Alemanha e os países da região, como o CIM, DED, DEG, DGRV, GTZ, KfW, PTB e o InWent.

- Cooperativa Alemã para a Cooperação Técnica, ou em alemão, Deutsche Gesellschaft für Technische Zusammenarbeit (GTZ). A Cooperação Técnica objetiva atuar junto às instituições e às pessoas, visando expandir sua capacidade de ação no contexto das metas de desenvolvimento acordadas entre o governo receptor do projeto e da Alemanha. A Cooperação Técnica realiza-se por meio de programas estabelecidos por acordo comum, a partir de um Convênio Intergovernamental (Ajuste complementar ao Acordo Básico de Cooperação Técnica Brasil-Alemanha), que define a participação de cada uma das partes.

A Organização para a capacitação internacional e desenvolvimento InWent Internationale Weiterbildung und Entwicklung gemeinnützige $\mathrm{GmbH}$, organização de desenvolvimento de recursos humanos, de formação contínua e de diálogo internacional. Seus programas internacionais de capacitação e diálogo dirigem-se a especialistas e executivos, bem como a líderes do setor privado, da política, da administração pública e da sociedade civil de todo o mundo. Por meio de seus programas de formação, de intercâmbio e de diálogo, cerca de 35.000 pessoas são capacitadas por ano. A InWent representa a maior iniciativa comum do Governo Federal Alemão, dos estados federados da Alemanha e do setor privado para a formação de profissionais e a cooperação em nível internacional. Têm nas suas sedes centrais em Bonn e em Colônia, além de outras mais de 30 localidades na Alemanha e no exterior. Possui aproximadamente 900 empregados e um orçamento de cerca de 130 milhões de Euros. O sócio principal é a República Federal da Alemanha, o comitente mais importante o Ministério Federal da Cooperação Econômica e do Desenvolvimento- BMZ.

As áreas de atuação da InWent são: aperfeiçoamento profissional de especialistas e executivos de países em vias de desenvolvimento; qualificação em âmbito internacional de jovens profissionais; capacitação de especialistas e executivos da 
Alemanha, de outros países industriais, bem como de países em transição; intercâmbio de experiências e diálogo internacional; diálogo político com organizações internacionais; atividades educativas e informativas relacionadas ao desenvolvimento a serem realizadas na Alemanha; e capacitação de especialistas da cooperação alemã para o desenvolvimento. ${ }^{27}$

Uma das representações oficiais da InWent na América Latina é a InWent Brasil, que atua desde janeiro de 1999. Essa agência é de suma importância para o desenvolvimento desse trabalho, pois a iniciativa pesquisada, iniciativa Somos Mercosul, é em parte implementada em trabalho conjunto com a InWent e os governos membros do bloco.

- CIM - Centro de Migração Internacional e Desenvolvimento. Tem atualmente dois programas, o primeiro para estrangeiros qualificados que vivem na Alemanha, e receberam na Alemanha experiência profissional e querem retornar ao seu país de origem e trabalhar em uma área importante de desenvolvimento político. Outro programa intermedeia especialistas alemães que querem atuar em instituições públicas ou privadas na América Latina.

- DED - Serviço Alemão de Cooperação Técnica e Social não tem projetos próprios, mas atende a solicitações de mão-de-obra das organizações parceiras nos países anfitriões. Suas principais áreas de atuação são: promoção da economia e da ocupação; promoção da democracia e autonomia local; proteção rural do desenvolvimento e dos recursos; tratamento civil dos conflitos e promoção da paz; saúde; instrução e trabalho público da política de desenvolvimento na Alemanha.

- KfW - Banco de desenvolvimento. Junto com outras instituições alemães de desenvolvimento, o KfW focaliza seus projetos nas áreas de extrema pobreza e de conservação da floresta tropical. Uma aproximação é o programa piloto para conservar a Amazônia brasileira, patrocinada pelos estados G7 (PP G7).

- DEG - Companhia Alemã de Investimento e Desenvolvimento. Investe em projetos rentáveis, de longa duração e com um desenvolvimento eficaz em todo o setor

\footnotetext{
27 Agência Inwent Brasil. Disponivél em: http://www.inwent.org.br/organizacao.html. Acessado em: 22.02.2010.
} 
econômico. Apóiam no Brasil principalmente empresas de pequeno e médio porte que estejam exportando.

- DGRV - Confederação Alemã das Cooperativas. No Brasil a Confederação pretende fortalecer as organizações cooperativas e incentivar a transferência de know-how nesta área por meio de treinamentos.

- PTB - Instituto Nacional de Metrologia. Fornece serviços científicos e técnicos. O PTB mede com a mais elevada exatidão e confiabilidade. Apoiou, por exemplo, no Brasil a implantação do Inmetro e prosseguiu na implantação do MNPQ (Medição, Padrões, Exame, Departamento de Qualidade, Certificação).

A Alemanha vai continuar a cooperar no contexto europeu e internacional da divisão do trabalho e a responsabilidade de trabalhar com outras nações para o desenvolvimento do mundo. Além disso, a Alemanha tem um forte envolvimento das igrejas, as fundações e as ONGs que participam ativamente na cooperação para o desenvolvimento em conjunto com o governo alemão, o acordo de coligação também prevê cooperações também com o setor privado.

\subsubsection{Cooperação alemã no âmbito do Mercosul}

A diferença social entre ricos e pobres na América do Sul é um grande desafio para essas jovens democracias, nas quais a população almeja por padrões de vida mais justos, pela diminuição da pobreza e por uma maior coesão na sociedade. Neste processo sócio-econômico, o Mercado Comum do Sul vem adquirindo um papel fundamental para lograr esse desafio, pois suas economias e mercados são estrategicamente importantes na região.

O Mercosul - com o seu relançamento em 2000 e com o apoio dos seus governos para um aprofundamento da integração entre os países do bloco e um notável crescimento das suas economias - tomou novas dimensões na conjuntura internacional. Nessa nova fase, o bloco reformula suas metas e lança o desafio de uma integração, não somente econômica, mas também social e cultural. A busca pelo aceleramento do processo de integração "mercosuliana" abre um novo espaço para um maior diálogo e um 
intercâmbio ativo entre os países membros, mas também o anseio de intercambiar experiências com países extra-bloco.

É claro que a União Européia é um parceiro importante nesse intercâmbio e nesse diálogo, principalmente no tema de integração entres os países europeus. Ela, como bloco, tem vasta experiência no tema e é hoje um dos poucos blocos que conseguiram evoluir para a etapa de Mercado Comum. A Alemanha, como um dos carros chefes, teve e tem um papel muito importante nesse processo integrativo europeu. Por isso, o programa alemão de cooperação ao desenvolvimento quer ajudar e cooperar com os países do Mercosul. Seu programa no Mercosul tem como principais vertentes reforçar o intercâmbio cross-country de experiências e ajudar a intensificar a cooperação regional entre os países em desenvolvimento, com as quais objetivam conseguir um maior diálogo transnacional entre os países membros, um apoio a o aprofundamento do processo de integração regional e uma institucionalização do bloco "mercosuliano", um marco que foi importante na evolução da União Européia.

Nos países do Mercosul a realização e a coordenação dos projetos específicos de desenvolvimento e direcionados ao bloco foram designadas à Agência alemã InWent, sobretudo o escritório da InWent Brasil, em São Paulo. Seu programa em andamento na região possui como principal objetivo a coesão social.

Os principais temas são: sistemas fiscais socialmente justos, responsabilidade social corporativa do setor privado, promoção de um diálogo regional entre os países do Mercosul sobre questões de política energética, lançando o questionamento do uso da energia renovável, e o apoio a uma participação mais ativa da sociedade nas decisões políticas do bloco e no seu processo integrativo. Os diálogos são acompanhados por especialistas com formação política nesses temas. Outro foco trabalhado no programa de coesão social é a qualidade da educação nos países do Mercosul e a formação de professores e profissionais em diversas áreas, principalmente de economia, engenharia, meio ambiente e ciência da computação. A InWent, em cooperação com os parceiros dos países membros do Mercosul, promove seminários, conferências, cursos de formação, diálogos, ou seja, lança bases para intensificar o conhecimento prático e intercâmbio de experiências entre profissionais dos dois blocos. 
O programa "Promoção da coesão social nos países do Mercosul", como é chamado, visa reforçar a responsabilidade social do Estado e do setor privado e ajudar a promover diálogos sobre a desenvoltura de políticas econômicas em níveis nacional e regional. ${ }^{28}$ Esse programa divide-se em três partes.

A primeira centra-se inicialmente em abrir debates e com isso ajudar no desenvolvimento de um projeto de sistema fiscal mais equitativo, que esteja de acordo com a realidade da população dos países membros do Mercosul. Uma tributação mais justa conduz a uma maior aceitação da política econômica e uma satisfação maior da população, assim também, um fluxo mais regular, menor número de inadimplentes e a diminuição de falta recursos por meio de impostos para os caixas governamentais. Com esse sistema, o Estado tem a oportunidade e a receita necessárias para fornecer fundos urgentes para necessidades sociais da população.

Nos fóruns de diálogos e nos seminários de formação da InWent são desenvolvidas em conjunto soluções para a pretendida reforma tributária. Experts de diversos países, tanto do Mercosul e como da União intercambiam diálogos, discussões e soluções.

De acordo com o pensamento da InWent, a justiça social pode ser alcançado a longo prazo, se todos os setores da economia, principalmente o privado, fizerem sua parte $\mathrm{e}$ aceitem as vantagens e perdas oferecidas de um sistema tributário mais justo.

$\mathrm{Na}$ segunda parte do projeto, a InWent promove programas de treinamento transnacionais e interdisciplinares, para os quais representantes de firmas da região, da sociedade civil e governantes são trazidos. Essa segunda parte do projeto funciona como uma plataforma de interação entre esses três setores e durante o treinamento são apresentados e discutidos diferentes conceitos socialmente responsáveis de governança corporativa - Responsabilidade Social Empresarial (RSE). Trata-se de gerar um compromisso permanente dos empresários e adotar um comprometimento ético e contribuir para o desenvolvimento econômico, simultaneamente, a qualidade de vida de seus empregados e de seus familiares, da comunidade local e da sociedade dos países "mercosulianos". Os participantes desses programas podem introduzir esse

\footnotetext{
28 Agência Inwent Brasil. Disponivél em: http://www.inwent.org.br/organizacao.html. Acessado em: 22.02.2010.
} 
conceito social nas suas empresas e melhorar o bem-estar geral e as condições de trabalho e também seu próprio bem-estar econômico. Essa concepção assume a responsabilidade social como expressão de uma postura ética comprometida com o resgate da cidadania, assumindo uma posição de co-responsabilidade, na busca do bem-estar público, em articulação com as políticas sociais (instituto, fundações, organizações, universidades, comunidade, etc).

A terceira parte desse programa de Coesão Social é o apoio ao CEFIR - Centro de Formação para a Integração Regional para o Mercosul junto a Iniciativa Somos Mercosul. Em junho de 2005 na cidade de Assunção no Paraguai, o presidente uruguaio Tavaré Vázquez assumiu a presidência Pro Tempore do bloco. Nesta ocasião, o Presidente uruguaio chama a Iniciativa Somos Mercosul à vida com seu discurso e uma exclamação: "Temos de admitir que todos nós Somos Mercosul!"

A Iniciativa Somos Mercosul é um projeto que tem a intenção de criar uma proximidade dos cidadãos com o bloco. Com uma base ampla de participantes (políticos, ONGs, organizações internacionais e governos internacionais) e uma agenda de temas diversificadas, a iniciativa lança um espaço significativo para um novo modelo temático do programa regional alemão de Cooperação para o Desenvolvimento, juntamente com os Pontos Focais, que são os coordenadores do projeto e representam cada país do bloco. Um funcionário do Ministério das Relações Exteriores de cada um dos quatro membros plenos é escolhido como Ponto Focal. Os quatro Pontos Focais serão aqueles que representarão o governo na iniciativa e coordenarão todo o processo de implantação desta em seu país.

\section{Iniciativa Somos Mercosul}

É hora de vir à frente com a construção do Mercosul urbano, pois este será o espaço democrático em que estamos a avançar corajosamente para concluir o nosso acordo. Temos de tomar em consideração sobre nós, que somos todos do Mercosul e que todos dependemos do sucesso desse grande projeto político. ${ }^{29}$

\footnotetext{
${ }^{29}$ Ser y Parecer. Balance de la Initiative Somos Mercosur. Montevidéu, 2007. Página 5
} 
A Iniciativa Somos Mercosul foi lançada por causa das demandas da sociedade civil frente aos governos membros por uma maior participação nas decisões políticas do bloco. Ela é uma resposta as demandas sociais e ao aumento das perspectivas sobre o potencial do projeto de integração. A iniciativa visa fortalecer as dimensões sociais, culturais e políticas do Mercosul como um complemento aos aspectos econômicos e comerciais, na qual se concentrou a idéia inicial desse processo de integração.

A iniciativa segue um desejo de envolver os cidadãos no processo de integração para produzir, neste sentido formar uma nova identidade regional cívica. Essa nova identidade deve ser acompanhada de resultados realistas, de transparência e de uma percepção, de que o processo de integração do Mercosul não é apenas uma obra das elites políticas e técnicas, mas também da diversidade da sociedade civil organizada.

\subsection{A definição da Iniciativa Somos Mercosul}

Para entender a Iniciativa Somos Mercosul, é necessário entender suas raízes e sua história. A plataforma Somos Mercosul foi criada durante a primeira presidência Pro Tempore ${ }^{30}$ da Frente Ampla [o atual partido progressivo no poder no Uruguai, nota adicionada pelo autor]. Então, teve que ser inventada uma plataforma social que poderia funcionar - sem qualquer trabalho, nem o de inseri-la no organograma oficial do Mercosul e nem de registrá-la - na perspectiva de uma sociedade civil regional - uma sociedade civil do Mercosul.

Por isso, o que era inicialmente o programa Somos Mercosul, era uma plataforma que foi posteriormente retomada pela seguinte presidência Pro Tempore. E isso, deu-lhe uma consolidação, uma formalização, que é de fato uma formalização bastante volátil de forma intencional. Ela não deve ser uma outra instituição no organograma do Mercosul, porque a sua oficialidade como

\footnotetext{
${ }^{30}$ O que é a Presidência Pro Tempore? É um mandato presidencial de cada país membro do Mercosul. Cada país membro do bloco, representado pelo seu suplente, assume a presidência do Mercosul por um período de seis meses. A presidência Pro Tempore corresponde à atuação e à coordenação de todas as decisões e todos os eventos, ou seja, reuniões, conferências, discussões, etc. A chamada presidência Pro Tempore é concebida em colaboração com a sociedade civil. Cada presidência Pro Tempore é caracterizada por preocupações específicas, relacionadas às questões e aos temas do país membro que a assume no momento.

A presidência Pro Tempore passa de um país para outro a cada seis meses, seguindo uma ordem alfabética, de acordo com o Protocolo de Ouro Preto. A presidência Pro Tempore de cada país é concluída com a reunião da Cúpula Presidencial do Mercosul, realizada no país da presidência. "O país que ocupa a presidência Pro Tempore defini as tarefas em coordenação com outras delegações, a agenda das reuniões dos órgãos do Mercosul, além de exercer a função de porta-voz em reuniões e fóruns internacionais ou em que está participando do Mercosul” (ver Decisão CMC N ${ }^{\circ} 14 / 91$ ).
} 
organização iria definir para ela limites. Porém, ela não deve ser tão pouco uma simples expressão dos atores sociais, que formaram uma aliança entre si. Por isso, a iniciativa é uma estrutura de dimensão regional, que os governos dos países membros do Mercosul, reconheçam, apóiem, mas não sejam dirigidas por eles. Então, eu acho, que ela se configurou como um instrumento de meio-perfil com uma formalização flexível, não tendo as limitações, que pertenceriam, por exemplo, o Fórum Consultivo, [...] mas tampouco a distância do governo, que teria uma simples rede social. (Gerardo Caetano - Diretor Acadêmico da Cefir) ${ }^{31}$

Inicialmente Somos Mercosul foi criado como uma iniciativa pública. A presidência Pro Tempore do Uruguai de 2005 definiu-a, depois, como uma plataforma para os atores sociais da integração regional. Houve várias reuniões, nas quais os atores foram capazes de discutir sobre a integração regional e o seu processo. Ela é oficial, reconhecida pelos governos e era parte da estratégia da iniciativa, não fazer parte do organograma do Mercosul, para não limitá-la. Ela deve ser configurada pela sociedade civil, e não pelos governos. A iniciativa é uma oportunidade para se comunicar diretamente com os governos. O objetivo é informar o público no processo, para discutir novas áreas, de fazer exigências e tomar parte na tomada de decisão.

Após a Presidência Pro Tempore do Uruguai, a iniciativa foi continuada e assumida pela Presidência Pro Tempore da Argentina, quando se criou então o programa Somos Mercosul. Esse ponto será descrito em detalhes na seção Somos Mercosul Argentina.

A Iniciativa Somos Mercosul foi uma expressão significativa da vontade política de democratizar o Mercosul. Ela criou novos espaços para a sociedade civil e os governos locais, nos quais eles dialogam, formulam suas reivindicações e podem ser incluídos no processo de tomada de decisão no bloco. Isso significa uma dinâmica aberta à participação da sociedade civil no âmbito do Mercosul por meio de uma institucionalização das suas organizações representativas, entre elas, o Fórum Consultivo Econômico e Social do Mercosul.

A origem desta iniciativa reside no programa de trabalho 2004-2006 do Mercosul e seu capítulo sobre "O Mercosul Social”. Em primeiro lugar, os objetivos da iniciativa devem ser de um esforço prático. Destina-se a alcançar resultados tangíveis, a fim de

\footnotetext{
${ }^{31}$ Gerardo Caetano em uma entrevista para a autora na Cúpula Social do Mercosul. Bahia, dez. 2008
} 
trazer benefícios visíveis para os cidadãos do Mercosul. É um programa de setores público e privado, que enfatiza as dimensões sociais, políticas e culturais como um complemento ao já desenvolvidas nas relações econômicas e comerciais. E é um programa de atividades sociais, políticas e culturais, organizadas pela sociedade civil e pela presidência Pro Tempore.

Durante a $28^{\text {a }}$ Cúpula Presidencial do Mercosul em 2005, o governo do Uruguai para assumir a presidência Pro Tempore entre os Estados-membros e distribuiu o documento intitulado Somos Mercosul. Foi salientado que a perspectiva da integração cultural do bloco para chegar à ordem do dia era uma tarefa fundamental na concepção de uma cidadania regional, a fim de obter a legitimidade necessária para o bom funcionamento do novo quadro institucional do Mercosul ${ }^{32}$. Assim começou a se formar o que mais tarde se tornou a regional Iniciativa Somos Mercosul, que depois foi retomado na presidência Pro Tempore da Argentina e do Brasil.

\subsection{A estrutura do Somos Mercosul}

A Iniciativa Somos Mercosul está estruturado em cada país membro pleno do bloco com um caráter e com características próprias. A coordenação da iniciativa é composta por quatro instituições, os chamados Pontos Focais. Cada um destes Pontos Focais é composto pelo governo dos países membros em cooperação com os atores regionais relevantes e com a InWent. Isso significa que em cada país membro há um Ponto Focal. Em cada uma destas instituições, há um coordenador ou um responsável pela iniciativa. Assim, existe para cada país do Mercosul um coordenador. Ele é um funcionário do governo local e foi nomeados pelo Ministério das Relações Exteriores.

Os Pontos Focais organizam com os governos nacionais e da sociedade civil regional a agenda social da Presidência Pro Tempore, e os seus temas e as reuniões que são realizadas durante a Presidência Pro Tempore cada membro em cada um dos países.

\footnotetext{
${ }^{32}$ Ibidem
} 


\subsubsection{Somos Mercosul Argentina}

Na Argentina, o Conselho Consultivo da Sociedade Civil (CCSS) do Ministério das Relações Exteriores é responsável pela iniciativa como Ponto Focal (Consejo de la Sociedad Civil Consultivo del Ministerio de las Relaciones Exteriores, Comércio Internacional y Culto). A pessoa de contato é o embaixador Oscar Lambord.

\section{Consejo Consultivo de la Sociedada Civil (CCSC)}

Em 2003, o Ministério das Relações Exteriores da Argentina reconheceu a necessidade de criar uma instituição que trabalhasse com as interligações entre as organizações sociais, a sociedade e as questões da integração. Este órgão governamental deve atuar como um instrumento para a articulação e para a participação das organizações sociais. O CCSC tem prioridades similares, como a difusão de informação, formação dos funcionários e da empresa e o apoio à organização da sociedade civil. Estes objetivos apresentam grandes similaridades com a iniciativa em destaque.

Deve-se ressaltar que a criação do CCSC ocorreu relativamente logo após a crise de 2001 na Argentina, que causou uma quebra em diversos setores do país. Havia um grande ceticismo das organizações sociais diante ao governo. O CCSC foi, por causa da crise de legitimidade da representação governamental, responsável pela reconstrução de laços sociais. A criação deste espaço era politicamente importante para o governo argentino. O governo e o Ministério das Relações Exteriores da Argentina contou na época do lançamento da Iniciativa Somos Mercosul, em 2005, com o apoio do Conselho Consultivo da Sociedade Civil para continuar a iniciativa. ${ }^{33}$

O núcleo do CCSC consistiu inicialmente de trinta organizações. Ele está sendo coordenado no momento pela Representação Especial para a Integração e para a Participação Social (Reips). Ele tem, desde em então, experimentado um crescimento exponencial de modo que hoje já são cerca de 1.300 organizações participantes. Devido ao grande número de temas no âmbito da sociedade civil organizada, 25

\footnotetext{
${ }^{33}$ Consejo Construtivo de la Sociedad Civil. Buenos Aires, 2009. Disponível em: http://ccsc.mrecic.gov.ar. Acesso em: 15.dez.2009
} 
comissões temáticas foram organizadas, que ao final foram divididas em seis áreas de trabalho $^{34}$ e de uma dessas áreas surgiu o atual Programa Somos Mercosul.

Uma característica da iniciativa Somos Mercosul na Argentina corresponde ao curso virtual Todos Somos Mercosul. O curso é posto em prática pelo método e-learning e leva cerca de dois meses. Esse curso é uma ferramenta de educação e informação, que visa expandir e aumentar o conhecimento e o impulso em relação a integração regional por todos grupo de cidadãos dos países membros do bloco.

O conteúdo do treinamento combina temas da globalização com os aspectos locais e setoriais do Mercosul. O curso é realizado de forma virtual através da Internet e por meio de CD-ROMs com o apoio de tutores, que orientam os participantes sobre o conteúdo. O curso é dividido em quatro seções:

- Antecedentes do Mercosul;

- Integração Produtiva;

- Fortalecimento da integração sul-americana;

- O papel das regiões e das cidades no processo de integração.

Na primeira fase em 2006 em uma versão teste do curso participaram cerca de duzentas pessoas da região e $65 \%$ dos participantes concluíram o curso. Esse curso interativo é uma oportunidade para que os atores não-tradicionais se informem mais sobre o bloco e se aproximem da estrutura de integração regional ${ }^{35}$. A fusão de Somos Mercosul Argentina com o Consejo de la Consultivo Sociedad Civil (CCSC) foi importante para o desenvolvimento da iniciativa na Argentina, pois nele a iniciativa uma base sólida para desenvolver-se de forma significativa.

\footnotetext{
${ }^{34}$ Racovschik, María Alejandra. La participación de la sociedad civil en el marco del nuevo modelo de desarrollo nacional y regional. Centro Argentino de Estudios Internacionales Programa Política Exterior Argentina, out. 2008. Pag. 12

${ }^{35}$ La participación de la sociedad civil en el marco del nuevo modelo de desarrollo nacional y regional. Pág. 19
} 


\subsubsection{Somos Mercosul Brasil}

No Brasil, o Ponto Focal é a Assessoria para Assuntos Internacionais da Secretaria Geral da Presidência da República. O coordenador é o Sr. Renato Martins. Dentro do governo brasileiro, a Secretaria Geral da Presidência da República do Brasil representa um interlocutor para a conexão e comunicação do governo com a sociedade civil, além de assessorar o presidente no desempenho de suas atribuições. Ela organiza conferências, seminários e outras atividades. Ela possibilitou com essa abertura ao diálogo com a sociedade civil, a formação de um espaço para discussão, que conseguiu progressos concretos para a integração regional.

A extensão da Iniciativa Somos Mercosul para o Brasil veio através do projeto Encontro com o Mercosul, em março de 2005. Esse projeto é uma cooperação dos setores brasileiros do FCES e do CPC, este último representava o Parlamento do Mercosul, respondendo às reivindicações das instituições sociais que desejavam discutir em detalhes o Mercosul e seu impacto sobre as políticas públicas locais.

Nos anos 2005 e 2006, foi realizada uma série de seminários nas regiões que se encontram nos extremos geográficos do Mercosul. A distância era desde então uma preocupação do Brasil, que por causa da sua larga extensão, tem dificuldades na distribuição das informações e no envolvimento no processo de integração de todas suas regiões. Algumas das cidades onde foram realizados estes eventos foram Recife (Pernambuco), Salvador (Bahia), Belém (Pará), Belo Horizonte (Minas Gerais) e Fortaleza (Ceará). Todas essas cidades pertencem à região Norte e Nordeste do Brasil.

Objetivos do projeto Encontro com o Mercosul:

- Aprofundamento da integração regional com o envolvimento da população local, fortalecendo e abrindo canais de participação social, a difusão de informações por meio do folheto "Encontro com o Mercosul" e a organização e execução de eventos, seminários e conferências.

- Criar uma identidade regional do Mercosul;

- Introdução do tema do Mercosul e o aumento e a circulação de informação sobre o mesmo; 
- Divulgação de informações utilizando ferramentas de comunicação nas universidades, empresas e organizações sociais;

- Informar a sociedade sobre a importância da integração regional e estimular o debate;

Esse programa foi conduzido até 2007 em cooperação com a FCES e CPC, o atual Parlamento do Mercosul. Durante a presidência Pro Tempore Brasil, em 2008, a reunião dos Pontos Focais discutiu um novo programa, que é uma extensão da Iniciativa Somos Mercosul, em nível mais próximo do local e do nacional no Brasil. Como conseqüência, em 6 de outubro de 2008 foi lançado o programa Mercosul Social e Participativo pelo presidente brasileiro Luís Inácio Lula da Silva (DecretoLei $\left.\mathrm{N}^{\circ} 6.594\right)$.

O Programa Mercosul Social e Participativo tem como objetivo promover o diálogo entre o governo do Brasil e organizações brasileiras da sociedade civil sobre as políticas públicas do Mercosul. Isso significa:

- Divulgação da política, das prioridades, das propostas de negociação e de outras iniciativas do governo brasileiro para o Mercosul;

- Promoção de debates nos domínios político, social, cultural, econômico, financeiro e comercial, que incluam aspectos relacionados ao Mercosul;

- Transmissão de propostas e sugestões ao Conselho e ao Grupo CMC e GMC a fim de chegar a um consenso com as organizações da sociedade civil.

A execução do Programa Mercosul Social e Participativo é proporcionada por recursos financeiros incluídos no plano de orçamento da Secretaria Geral da Presidência. A criação de um bugdet direcionado ao programa representa um grande avanço no financiamento do programa de integração regional. Em geral, para a maioria dos programas de iniciativa do Mercosul não tem previsto ou à disposição nenhum tipo financiamento público. 


\subsubsection{Somos Mercosul Paraguai}

No Paraguai, o Ponto Focal é a Secretaria Geral do Ministério das Relações Exteriores. O coordenador é o embaixador Victor Peña. O desenvolvimento da iniciativa no Paraguai sofreu com a sua desordem política, social e econômico e com outras fraquezas do país.

“O Paraguai é o país mais frágil economicamente e politicamente do Mercosul, devido à sua economia agrícola orientada para a exportação", e também é o país menos industrializado da região do bloco, de acordo com o reporte do Banco Mundial.

É um país que tinha até pouco tempo uma situação política desestabilizada, diferenças extremas de interesses internos, em particular em relação ao Mercosul, e isso produziu uma forte agitação política interna e externa no país. Além disso, havia uma forte desconfiança dos investidores estrangeiros, pois o país não possuía credibilidade internacional suficiente. Apesar de todo o esforço do Ponto Focal paraguaio, o desenvolvimento da iniciativa dentro desse país dividido por interesses acontece de forma difícil.

O Paraguai no Mercosul assumia, até a eleição do novo presidente, o papel de freio, que anteriormente era realizado também pelo Uruguai, sob o governo [anterior a Vazquez]. A tolerância das bases militares americanas no solo paraguaio propagava grande preocupação entre os membros do bloco. (Nota do autor)

Em setembro de 2008, o novo presidente, Fernando Lugo Méndez, foi eleito democraticamente no Paraguai. O novo governo identifica-se com outros governos do Mercosul pela sua onda progressiva e seus ideais desenvolvimentistas. Pode-se afirmar que desde então existem expectativas positivas e perspectivas sobre o novo governo do Paraguai e sua atitude em relação a integração regional.

Em primeiro de setembro de 2008, quando Fernando Lugo Méndez foi eleito presidente da República do Paraguai, os Estados-Membros do Mercosul postularam: 
"O processo de integração regional está intimamente ligado com o pleno respeito à democracia e à suas instituições governamentais e o Mercosul reitera o seu apoio às instituições democráticas paraguaias, e ao seu presidente, eleito democraticamente pela população paraguaia".

\subsubsection{Somos Mercosul Uruguai e Cefir}

No Uruguai, o Ponto Focal é o Ministério das Relações Exteriores e o país tem como coordenador o Sr. Federico Gomensoro. Ali, a Iniciativa Somos Mercosul trabalha estreitamente com o Centro de Formación para la Integración Regional (Cefir), que assume a função de Secretaria Técnica da iniciativa, e conta também com o apóio da Fundação Friedrich Ebert no Uruguai (Fesur).

A estrutura do Mercosul no Uruguai é uma rede composta por várias organizações sociais, tais como Cefir e Fesur, movimentos como o Mercosul Social y Solidario, redes, sindicatos, cooperativas, organizações feministas e outros. Essa rede da sociedade civil é independente do governo, mas tem uma estreita relação e proximidade com o governo.

Uma característica marcante do Somos Mercosul no Uruguai é que a iniciativa não está fortemente envolvida com o governo. Com o apoio financeiro e estrutural do Cefir, a iniciativa pode de forma independente e autônoma estruturar sua agenda em conjunto com a sociedade civil e organizar seminários, conferências e workshops. O Cefir "classifica-se como algo intermediário entre a sociedade civil e o institucional do Mercosul, que atualmente é representado em primeira linha pelos governos dos Estados membros e pelo Parlamento". 36

Em 2006, o Governo do Uruguai teve a vontade e o engajamento de aprofundar a iniciativa e confirmou esse desejo com a revitalização do Cefir. Isso, resultou uma relação político e institucional estreita entre as duas Instituições. O Cefir encontravase em um processo de reforma institucional, a qual buscava redefinir novamente seus campos de atuação.

\footnotetext{
${ }^{36}$ Dynamik der Grenzen und kulturelle Integration. Interview mit Achim Wachendorfer und Rafael Piñeiro. Página 248-249
} 
Cefir foi fundado em 1993 pelo Grupo de Rio como Centro de Informação Europeu . Em 2006, ele foi reformulado como um centro especializado independente de treinamento para a integração regional do Mercosul, que é patrocinado pela InWent. Ele evoluiu para um instituto de formação, que acompanha ativamente os processos de integração regional na América Latina e apóia o diálogo político com a União Européia, por meio de reuniões, seminários de pesquisa e assistência proativa. Ele é também o secretariado técnico da Iniciativa Somos Mercosul no Uruguai.

O trabalho de Cefir baseia-se tematicamente nos seguintes eixos:

- Concentração do trabalho no processo de integração do Mercosul e seus países membros;

- Estreita cooperação com as organizações regionais da sociedade civil no Mercosul, especialmente com a Iniciativa Somos Mercosul. Intensificação de um trabalho conjunto com as instituições oficiais do Mercosul (CRPM, Secretaria etc.);

- Orientação e tratamento de "novas questões" que foram priorizadas na agenda recente do processo de integração (dimensões política, social e cultural);

- Complementar as relações intergovernamentais através da promoção de iniciativas e estruturas supranacionais no âmbito do Mercosul;

Com o objetivo de ampliar o diálogo e a coordenação entre as organizações da sociedade civil, o Cefir integra em suas atividades de formação reflexões sobre o contexto em que se dá o processo de integração regional, assim como os níveis e as formas de participação da sociedade civil.

O principal objetivo da cooperação com a iniciativa Somos Mercosul conseguir reforçar o contatos entre os dirigentes das instituições políticas de integração e a sociedade civil. O aprofundamento destas conexões não é limitado ao nível de governo e de instituições regionais, mas também, aos meios de comunicação, as empresas, as associações de consumidores, as universidades e ONGs. Essas interligações são a possibilidade de debater questões específicas e de refletir uma perspectiva sustentável, assim como melhorar os instrumentos e implementação das mudanças necessárias para fortalecer a sociedade civil. 
Nesse sentido, o Cefir é uma plataforma para o intercâmbio de opiniões dos cidadãos e de suas organizações, o que contribui para o discurso sobre a política social e para a tomada de decisões, além de estimular a promoção de uma relação construtiva entre os diferentes atores.

\subsection{Objetivos e a participação do governo alemão na iniciativa}

Quais seriam os objetivos do governo alemão com o apoio e financiamento de parte do programa Somos Mercosul? A agência de cooperação alemã InWent trabalha em conjunto com o Cefir, enquanto esse promove, como já citado na sua estrutura, seminários e conferências periodicamente, além de disponibilizar sua sede para eventos da sociedade civil organizada da região. É bom lembrar que o próprio Cefir é parte das organizações sociais do Mercosul.

Para combater as causas estruturais da desigualdade no Mercosul e garantir os direitos dos cidadãos, InWent promove com seu apoio ao Somos Mercosul o fortalecimento da democracia e do Estado de Direito, a fim de melhorar a participação dos mais pobres e desfavorecidas na região.

As preocupações centrais do seu trabalho são:

- O respeito, a proteção e a garantia dos direitos humanos - por meio do reforço da participação social;

- A promoção do controle parlamentar e cívico dos governos;

- A melhoria do sistema de justiça;

- A promoção da participação política e econômica dos povos indígenas e mulheres;

- A promoção da boa governança nos domínios das finanças públicas com o objetivo de redução da pobreza.

Somos Mercosul foi desenvolvido como uma plataforma para o diálogo político. Essa iniciativa se concentra em melhorar o diálogo entre Estado e sociedade civil e melhorar os mecanismos de apoio para a resolução pacífica de conflitos. Além de seus documentos oficiais, poderíamos falar dela como uma representação independente, que tem sua agenda própria, com a qual a cooperação alemã não se 
envolve.

A agenda de temas é desenvolvida com a sociedade civil durante as cúpulas sociais e também durante as reuniões locais feitas pela presidência Pro Tempore. De acordo com o autor, o apoio ao Somos Mercosul é uma promoção ao diálogo e ao intercâmbio de pensamentos e experiências. Com seu apoio direto, o governo alemão possui um interlocutor direto a sociedade civil. Essa cooperação abriu um novo espaço, que vai além de diálogo para a sociedade civil. Esse instrumento de interlocução é importante para observar os resultados reais da iniciativa diante da população. Ela serve método de avaliação dos projetos, é possível a partir do diálogo com a sociedade civil, saber como o programa evoluiu e como foi seu verdadeiro alcance de suas metas na região.

A cooperação garante também uma maior aproximação entre os acadêmicos, especialistas e atores da sociedade civil dos países membros e da Alemanha. A agência alemã acredita na revitalização de intercâmbio entre os especialistas alemães e do Mercosul. Com essa cooperação o governo alemão passa a estabelecer um diálogo direto com a população, o que facilita a divulgação das notícias sobre o que se passa ali e facilita também a divulgação das necessidades locais. Essa interlocução feita pelo Somos Mercosul é um fator importante no tema de reforma do organismo alemão e no sucesso das cooperações para o desenvolvimento, pois a partir do contato direto com a população é possível saber suas barreiras para o desenvolvimento e suas falhas. É importante enfatizar que por meio da cooperação alemã não há aproximação com o governo do Mercosul, ou seja, não há como utilizá-lo como ponte para futuros projetos econômicos e políticos. A organização e realização da agenda no Uruguai acontece por parte da sociedade civil com forte participação conjunta da Fundação Friedrich-Ebert e Cefir. Em alguns eventos haverá a participação da agência InWent Brasil, porém sua participação será dentro do seu programa de coesão social e de responsabilidade social no Mercosul, que não abrange a Iniciativa Somos Mercosul.

Consideramos que o apoio à cooperação e o financiamento de parte dos eventos da iniciativa não estão atrelados a nenhuma vantagem financeira direta concedida dos países cooperados ao país cooperante. A cooperação interessa-se em ajudar o desenvolvimento da região, e esse interesse é motivado pela compreensão de que, no 
sistema econômico global, os países dependem um do outro. Os países do Mercosul são importantes parceiros econômicos da Alemanha. Crises financeiras e econômicas no Mercosul podem provocar redução de vagas de emprego na Alemanha. A estabilização e o desenvolvimento por meio de cooperações visa portanto fortalecer economias sul-americanas, as quais, por sua vez, fortalecem também a economia alemã. A Cooperação para o Desenvolvimento não traz progresso somente aos receptores, mas também vantagens aos doadores.

Por último, vale ressaltar que a Iniciativa Somos Mercosul é uma forma de manter a Cooperação para o Desenvolvimento na região. Com o passar dos anos, a Ajuda ao Desenvolvimento vem diminuindo na América Latina, principalmente na região do Mercosul, no México e no Chile $^{37}$. Essa cooperação tem ainda características especiais pela sua independência da realização dos eventos, principalmente no Uruguai. O Cefir é hoje uma grande plataforma, que promove o diálogo dentro da sociedade civil, além de ser uma secretaria pronta a ajudar logisticamente e como parceiro acadêmico do governo alemão na realização de seus eventos, principalmente no Uruguai e na Argentina.

\subsubsection{Financiamento da cooperação alemã para o desenvolvimento}

O governo federal alemão estabeleceu o objetivo de alcançar até 2015 uma taxa de $0,7 \%$ do rendimento nacional bruto à assistência oficial ao desenvolvimento (Official Development Assistance, a APD curta). Apesar da difícil situação orçamental, o Governo Federal incluiu no seu projeto de orçamento para o ano de 2010 um aumento substancial do financiamento para o Ministério do Desenvolvimento. Ao mesmo tempo, o controle da eficácia da cooperação para o desenvolvimento será ainda maior - essa é uma das prioridades de trabalho do BMZ, que vem em conjunto com a sua reforma já iniciada.

\footnotetext{
${ }^{37}$ Tovar, Camilo, Balbis Jorge. Mito y Realidad de la Ayuda Externa América Latina al 2009. Una evaluación independiente de la cooperación internacional al desarrollo. Capitulo VII.La búsqueda de una mayor eficacia en la cooperación al desarrollo entre la unión europea y américa latina. ALOPMéxico, set. 2009. Pág. 39.
} 
A eficácia é crucial para a melhoria das condições de vida nos países parceiros, bem como a legitimidade da política.

Tabela de financiamento do BMZ (em Euro):

\section{BMZ Haushalt 2009 [in Tausend Euro]}

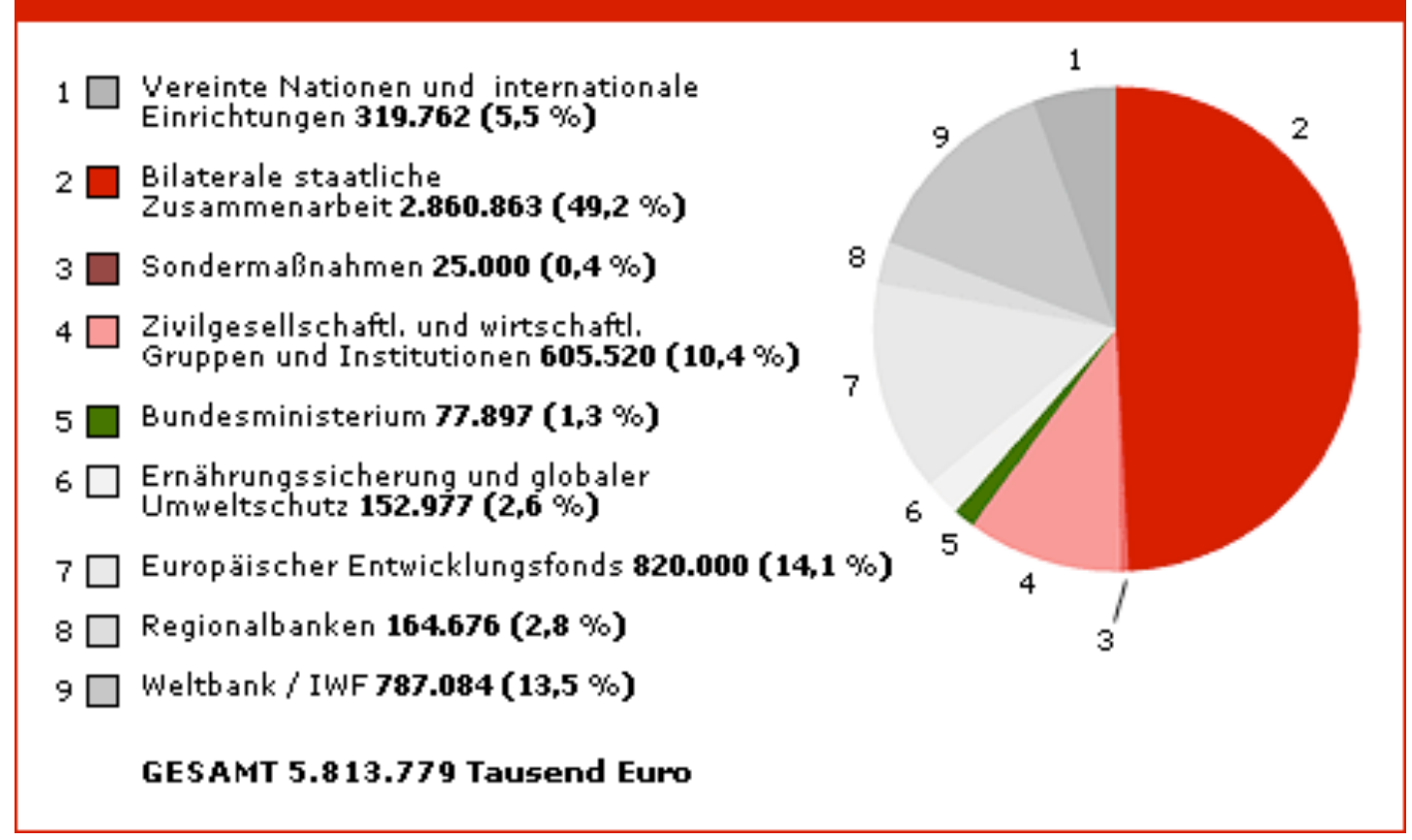

Fonte: BMZ 2010

Legenda: 1. Nações Unidas. 2. Cooperação bilateral 3. Medidas especiais 4. Sociedade civil, grupos econômicos e instituições 5. BMZ 6. Segurança alimentar e proteção ambiental 7. Fundo de desenvolvimento europeu 8. Banco regional 9. Banco Mundial e FMI

\section{O resultado da Iniciativa Somos Mercosul 2009}

\subsection{Balanço Somos Mercosul}

O ano de 2009 foi marcado por muitas turbulências, muitos êxitos e novos desafios por conta dos novos governos no Paraguai e no Uruguai. No primeiro semestre, a presidência Pro Tempore do bloco foi do Paraguai. O presidente, que tinha sofrido um desgaste da sua imagem pessoal por causa de alguns escândalos, reafirmou seu direcionamento político e confirmou as expectativas de mudanças da posição política do Paraguai diante do bloco. 
O ano de 2009 foi aberto com uma nova etapa de cursos Todos Somos Mercosul, tendo a responsabilidade de aproximar os cidadãos das noções básicas e informar-lhes sobre a estrutura e história do Mercosul. Assim, o curso - desenvolvido em conjunto pelo Programa Somos Mercosul, pelo Cefir e pela Subsecretaria da Chancelaria Argentina para Integração Econômica Americana e do Mercosul - intenciona aumentar a participação dos cidadãos no debate sobre o modelo de integração que está sendo construído.

Em 2009, dois fatos foram favoráveis à confirmação do envolvimento e do desejo por parte do governo de continuar a fortalecer a integração regional. A deposição do presidente hondurenho Manuel Zelaya é o primeiro deles, que uniu o bloco em torno de uma postura única. A decisão declarada em conjunto, como bloco, foi uma atitude importante para a imagem do Mercosul. O acontecimento porém mais importante para a iniciativa foi a realização da primeira Cúpula Social em Assunção, no Paraguai. Desde da inauguração da iniciativa, nunca foi realizado uma cúpula social no Paraguai. País tido como freio para a dinâmica da integração regional, afirma com o novo governo seu compromisso de avançar e reforçar a iniciativa, que pareceu sempre tão frágil no país. A Cúpula Social foi realizada entre os dias 22 e 23 julho de 2009. Ela foi dividida em quatro eixos temáticos - energia, trabalhadores, juventude e religião - e organizada pela chancelaria paraguaia em parceria com a sociedade civil paraguaia.

Outro avanço na questão da integração social foi a inauguração do Instituto Social pelo presidente Fernando Lugo, projeto que estava no papel desde 2008. Durante sua inauguração o presidente Lugo declara no Boletim Somos Mercosul:

Acreditamos e proclamamos o processo de integração, onde a vida das pessoas é mais importante. Portanto, acreditamos no Mercosul Social, direcionado ao desenvolvimento integral de direitos que garantem a igualdade de oportunidades. Neste momento, devemos mencionar a nossa crença e o nosso compromisso com o aprofundamento das instituições sociais e a estrutura organizacional do Mercosul.

O encerramento da presidência paraguaia foi acompanhada de progressos e planos 
para o fortalecimento do grupo. A cúpula presidencial, que acontece logo após da social, foi festejada com sucesso tanto pela sociedade civil como por empresários da região. Ela tratou de um tema que por muito tempo esteve em discussão, que é a eliminação da cobrança dupla. Mais de 100 produtos terão até dezembro de 2011 cada um sua Tarifa Externa Comum (TEC) em vigor. A eliminação da obrigatoriadade da cobrança dupla do TEC significa um grande avanço para a união aduaneira dos países da região. Outra questão resultante da cúpula presidencial foi a flexibilização dos créditos do Fundo de Convergência Estrutural do Mercosul (Focem). A solicitação feita pelo Uruguai e pelo Brasil foi de que o Focem também passasse a ser habilitado para projetos industriais e privados. Uma outra discussão lançada pelo o Brasil foi a substituição do dólar por moedas locais para as transações comerciais do bloco. Essa medida de substituição do dólar já foi adotada pela Argentina e pelo Brasil em suas negociações.

Um êxito importante da iniciativa foi a criação de uma rede regional de universidades públicas na região. A proposta ganhou o título de "Universidade do Mercosul". A declaração final conjunta dos presidentes destacou a Cúpula de Assunção das demais. Trata-se novamente de um gesto de apoio ao presidente deposto de Honduras, sendo a questão integrada à sua declaração final. No segundo semestre de 2009, a presidência Pro Tempore foi presidida pelo Uruguai. A presidência do Uruguai foi acompanhada de muita expectativa, pois essa seria a última Cúpula Social com seu fundador Tabaré Vaquez.

No início da presidência, o assunto mais discutido foi o novo acordo do Brasil e do Paraguai com relação ao preço da energia produzida pela hidrelétrica Itaipu. A assinatura desse acordo é um marco:

[...] construindo uma nova etapa na relação bilateral. Tal
documento, considerado por ambas as partes histórico, de fato
promove o fortalecimento do relacionamento bilateral entre as
partes e cria expectativas de um futuro mais promissor para o
Paraguai e até mesmo para o projeto de integração "mercosulino". ${ }^{38}$

${ }^{38}$ Blanco, Luis Fernando. O novo acordo brasil-paraguai e a renegociação do tratado de Itaipú. Enfim
uma postura de liderança sub-regional? Fundação Konrad Adenauer. Rio de Janeiro 2009. 
Três temas foram de grande importância durante esse segundo semestre. Eles foram a questão de proporcionalidade do Parlamento do Mercosul, o ingresso da Venezuela aprovado pelo congresso brasileiro e, finalmente, um tema importante na defesa do continente da América do Sul: a ingerência das tropas dos Estados Unidos na Colômbia.

O Cefir, no começo do segundo semestre, abriu espaço para os internautas de toda região no curso online sobre a integração regional. No começo do ano, já tinha criado o curso presencial. As aulas são dadas segundo método chamado "e-learning, aprender à distância pela internet”.

O Cefir inovou também na contextualização da iniciativa, que foi o Festival Latinoamericano. Bandas da região tocaram durante todas as segundas-feiras no Teatro Solis, em Montevidéu, em favor da integração. Não é a primeira vez que a presidência Pro Tempore do Uruguai aposta e fomenta a integração cultural da região. Desde a criação da iniciativa, o Cefir tenta inovar, abordando novos temas culturais e sociais na agenda do Somos Mercosul.

O Parlamento do Mercosul - depois dos 10 anos de criação, em 2008, da Declaração Sócio-laboral do Mercosul -, analisa suas mudanças. Durante esse semestre, no setor educacional, houve uma evolução substancial. A União Européia assinou novo acordo com o Mercosul, que assegura a mobilidade de estudantes universitários entre os países dos dois blocos. Importante tema para o Somos Mercosul que é o diálogo e intercâmbio entre profissionais de um lado e outro do atlântico.

Como já abordamos, houve uma grande expectativa em torno da Cúpula Social no Uruguai. Depois de dois dias intensos de trabalho, um antes e outro depois da Cimeira de Chefes de Estado, cerca de 200 participantes da Cúpula Social reuniram-se, em 7 de dezembro de 2009, em quatro grupos temáticos (agricultura familiar; comunicação, informação e transparência; Juventude; e Saúde e Deficiência), afirmando o papel da cidadania no processo da integração regional.

A documentação produzida durante os sete dias foi entregue dois dias depois para os governos do bloco, em uma atividade que foi chamado de "Diálogo com os governos da América do Sul”, realizada na sede da Cefir. Essa última foi um grande passo para 
a iniciativa, pois a falta de participação do governo sempre foi uma das dificuldades para seu desenvolvimento.

A procura de novos espaços de participação da sociedade civil, a
condenação do golpe de Estado em Honduras e a implementação de
políticas públicas regionais buscando 'soluções comuns para
problemas comuns' faziam parte do núcleo de decisões da Cúpula
Social, que pediu aos governos regionais um programa para a
juventude, a unificação do Parlamento do Mercosul, melhores
políticas para pessoas com deficiência, criação de um grupo regional
voltada para o tema da agricultura familiar e uma maior coordenação
entre os países na regulação do conteúdo dos meios de
comunicação.

Mas a grande surpresa ficou por conta da volta das negociações para um acordo comercial do Mercosul com União Européia. Foi talvez uma das questões mais importantes desenvolvidas na última Cimeira de Chefes de Estado do Mercosul, realizada na segunda semana de dezembro 2009, em Montevidéu. Após cinco anos de estagnação, o bloco mostrava se mover para retomar as negociações com a União Européia (UE) em busca de um acordo de associação inter-regional. Até hoje o possui somente três acordo comerciais transatlânticas, uma é com Israel, a segunda com a Índia e a mais recente o acordo com SACU- Southern Africa Customs Union. Conforme acordado naquele momento, a tarefa de fechar o acordo com UE será levada adiante pela Argentina, país responsável pela atual presidência do Mercosul. A presidenta Cristina Fernandez disse querer explorar os pontos de concordância e discordância entre Mercosul e União Européia antes do mês de maio - quando será realizada em Madri a UE, América Latina e no Caribe. A notícia foi recebida pela sociedade civil com bastante desconfiança, principalmente por alguns grupos da sociedade civil.

\subsection{Desenvolver mecanismos de participação da sociedade civil através da Iniciativa Somos Mercosul}

A Iniciativa Somos Mercosul é um mecanismo criado para reforçar a participação da

${ }^{39}$ Boletim Somos Mercosul- Cefir. Edição dezembro 2009 
sociedade civil no projeto de integração regional. Por meio dela foram postas ao alcance da sociedade civil algumas ferramentas de participação.

Uma dessas ferramentas é a Cúpula Social do Mercosul, um espaço participativo e aberto, que diferentemente do Fórum FCES - que limita o número de participantes a nove por país-membro -, não define um número máximo de participantes. Por não pertencer ao organograma oficial do Mercosul, a cúpula tem liberdade para escolher sua agenda e temas a serem discutidos nas reuniões, sem precisar ir de acordo com os ritos e com a prazos do bloco. As organizações sociais do Mercosul reivindicaram uma participação mais regular, a fim de passarem a dialogar com mais freqüência com o governo sobre as dificuldades do processo de integração. A intenção era também integrar as propostas elaboradas por eles à pauta da Cúpula Presidencial. Isso levou à formação de mecanismos para a participação da sociedade civil, como a Cúpula Social do Mercosul e do Boletim Somos Mercosul.

\subsubsection{Boletim Somos Mercosul}

A falta de transparência no Mercosul é marcante na sua gestão transnacional e no desenvolvimento do processo de integração.

Desde a formação do Mercosul até o lançamento do Boletim Somos Mercosul, existiu um deficit de informações sobre o processo de integração "mercosuliana" nos níveis cultural, político e social. A maioria das informações sobre o bloco e seu desenvolvimento circulava em torno dos políticos, mas não chegava ao conhecimento dos cidadãos e dos meios de comunicação, o que projetava uma imagem elitista do bloco. Essa falta de transparência gerou um ceticismo da imprensa regional com relação ao bloco.

Considerado desinteressante e de difícil acesso, logo, o Mercosul deixou de ser mencionado nos grandes meios de comunicações. Quando algo era anunciado, geralmente estava ligado aos escândalos envolvendo ações ou representantes pontuais do bloco. Toda essa problemática gerada pelo déficit de transparência acabou criando 
uma imagem de descrédito da opinião pública perante o Mercosul. ${ }^{40}$ As falhas na comunicação ou na divulgação das ações do Mercosul foram decorrentes de um sistema não-estruturado e desarticulado. O Mercosul não possuía até 2007 uma secretaria ou uma sede para o bloco, que agora está em Montevidéu. Essa sede ainda não possui uma sessão de comunicação.

A falta de clareza na comunicação interferia também no trabalho dos atores sociais, que se esbarravam em dificuldades tanto quando tentavam se atualizar quanto quando tentavam participar do processo ${ }^{41}$. Em resposta à falta de representatividade da sociedade civil e à falta de clareza das informações que chegavam até a população, criou-se o Boletim Somos Mercosul em dezembro de 2006. Trata-se de, como o próprio nome já diz, um boletim publicado semanalmente de forma eletrônica. A opção por um instrumento de comunicação eletrônico é explicada pela sua facilidade de difusão. O boletim é mandado semanalmente como newsletter para os seus assinantes ou pode ser consultado de forma gratuita no endereço www.somosmercosur.org.

O Boletim Somos Mercosul tem a missão de acompanhar a presidência Pro Tempore do bloco e de divulgar as informações sobre seu desenrolar. Seu objetivo é manter os cidadãos atualizados sobre os acontecimentos no âmbito da integração regional e sobre as discussões realizadas com a sociedade civil organizada, quanto às dificuldades de percurso e as perspectivas para presidência Pro Tempore. Ele integra todo um conceito de democratização da informação que caminha para estimular a formação de uma consciência cidadã e o direito a informação sobre as transformações e avanços do bloco, que poderão afetar futuramente suas vidas: "A ação da comunicação é a chave para o fortalecimento da integração regional” ${ }^{\star 42}$. Além disso, colabora para transparência no bloco, que é um dos objetivos da Iniciativa Somos Mercosul,.

A criação do Boletim Somos Mercosul representa o progresso da cooperação ativa entre os Estados-membros a respeito da comunicação e do aproveitamento das

\footnotetext{
${ }^{40}$ Vorlauf des Somos MERCOSUR. CEFIR, 2008. Pag. 1

41 El MERCOSUR por dentro. Pag. 98

${ }^{42}$ MERCOSUR Social y Participativo. Pag. 106
} 
potencialidades das novas tecnologias acessíveis ${ }^{43}$. O Boletim quer contribuir contra qualquer abuso de poder por parte dos governantes e deseja mediar uma visão realista do desenvolvimento e da situação dos acordos do Mercosul.

Hoje o Boletim tem cerca de 16.000 leitores na região, registrados como destinatários de sua newsletter. A maioria dos membros estão relacionados às organizações da sociedade civil. ${ }^{44}$ Resulta daí o fato de que o boletim tenha se tornado a principal fonte de informações sobre a integração social e cultural do Mercosul.

Infelizmente, o Parlamento do Mercosul formado em 2007 tem falhas na comunicação com o exterior. Não há oficialmente nenhum departamento de comunicação na organização do Mercosul e suas seções estão sendo redesenhadas e com freqüência não dispõem do número de profissionais necessário. Além disso, a maioria dos boletins ou até algumas páginas de internet dos órgãos do Mercosul, como o do Secretariado, é antiga e contém poucas informações sobre os processos de integração em curso $^{45}$.

Embora o Boletim Somos Mercosul revele-se exitoso instrumento de informação, apresenta também suas deficiências. Ele é escrito em espanhol e não traduzido para o português, o outro idioma oficial do bloco. Além disso, a Iniciativa Somos Mercosul recebe pouca atenção no boletim. Seu site foi reformulado em 2009 pelo Cefir, que como secretaria técnica da iniciativa no Uruguai, tem trabalhando em cooperação com os diversos órgãos do Mercosul - Secretaria do Mercosul, CRPM e Mercocidades. Ele quer desenvolver um plano para a construção de uma rede de comunicação no âmbito do Mercosul. Trata-se de reforçar a comunicação no entre os atores, cidadãos e o Boletim, como poderosa ferramenta nesse processo. Uma outra deficiência seria a falta de interação dos cidadãos com os assuntos atuais do bloco, não possuía oportunidades para a população do bloco discutir e dar opiniões sobre o estado do desenvolvimento do bloco.

\footnotetext{
43 MERCOSUR Social y Participativo. Pag. 106

${ }^{44}$ CEFIR.Vorlauf Bulletin Somos Mercosur, Montevideo 2008

${ }^{45}$ Ver a página www.Mercosur.int, na qual se encontra boletins até 2005.
} 


\subsubsection{Cimeira Social}

Em fevereiro de 2006, foi realizada uma reunião por iniciativa da Fundação Friedrich Ebert Uruguai, da qual participaram os pontos focais da Iniciativa Somos Mercosul, representantes de várias organizações sociais, uma delegação do CPC, o coordenador da União do Sul (CCCS), a Rede de Mercocidades, o Presidente da CRPM Carlos Alvarez e outros. Na reunião, foi definida minuciosamente a estrutura do Somos Mercosul, que desde o começo intencionava reunir a sociedade civil, os governos e as instituições do Mercosul. Colocando esses três grupos sociais juntos, criaram-se condições para a convocação do "Primeiro Encontro por um Mercosul Produtivo e Social", que foi realizado em julho daquele ano, na cidade de Córdoba, como parte do conjunto de eventos da $30^{a}$ Cúpula Presidencial do Mercosul. O objetivo dessa reunião era aprofundar a participação da sociedade civil, em particular das organizações regionais no processo de integração. ${ }^{46}$

Com a participação de 500 representantes de organizações da sociedade civil, o evento foi um sucesso. As expectativas da reunião foram largamente superadas, e como resultado da troca de idéias e dos debates foi criada uma agenda com 41 Pontos, a serem trabalhados pela sociedade civil em conjunto com o Mercosul. Imediatamente após Córdoba, o presidente do Brasil, Luís Inácio Lula da Silva, convocou todos a se engajarem na implementação da agenda. Dando seqüência aos acontecimentos, o país realizou a Primeira Cúpula Social do Mercosul, na cidade de Brasília.

Como se pode definir a Cúpula Social? Podemos começar pelo seguinte: Trata-se de um espaço para discussão sobre política regional, participação social e agenda social do Mercosul. O foco da cúpula repousa sobre o "desenvolvimento regional e a participação social: o Mercosul que temos, para o Mercosul que nós queremos”.

Os objetivos da Cimeira Social:

- Ampliação e consolidação do Somos Mercosul;

- Promoção e construção da participação social;

- Promoção de uma identidade supranacional da cidadania regional;

\footnotetext{
${ }^{46}$ La participación de la sociedad civil en el marco del nuevo modelo de desarrollo nacional y regional. Páginas 21-23
} 
- Sistematização e divulgação da agenda sócio-ambiental do Mercosul;

- Promoção política, cultural e produtiva do bloco;

- Influência na agenda política do Mercosul;

- Promoção da educação da população local.

A Cimeira Social foi criada após o consenso de que o processo de comunicação iniciado em Córdoba deveria não só continuar, mas ser reforçado. Essa iniciativa funciona portanto como um mecanismo de articulação entre os cidadãos e os governos do bloco, tentando manter o diálogo social dentro do espectro regional, colaborando para a aproximação da população dos países que integram o Mercosul.

A Cúpula Social do Mercosul não é uma "contra-cúpula", mas uma reunião durante a qual se deve construir uma crítica construtiva. Ela é realizada em conjunto com o governo. Uma de suas peculiaridades é que, apesar de contar com a participação do governo, ela não é uma cimeira oficial. Ela sustenta a idéia de criar um espaço de convergência entre os governos, sociedades e instituições do Mercosul ${ }^{47}$.

A Cúpula é dividida em blocos, que acontecem de forma paralela. Cada bloco tem seu tema. Durante os três dias de duração dessa cúpula são discutidos intensamente tópicos sociais, ambientais, culturais e sócio-econômicos como: migração, emprego, educação, justiça e gênero, agricultura familiar, juventude, cultura, população, meio ambiente, sociedade da informação e modelo energético.

As trocas de conhecimentos, a exposição de problemas e busca de soluções mostram a vitalidade e a diversidade do Mercosul Social. O engajamento das organizações sociais e a vontade de avançar com a integração facilita e ativa o diálogo com representantes do governo regionais. O evento representa um avanço na importância do Mercosul como um espaço comum a todos ${ }^{48}$.

A Cúpula Social do Mercosul é uma atividade do Somos Mercosul e dos seus parceiros institucionais, que são Foro Consultivo Econômico e Social (FCES) e a

\footnotetext{
${ }^{47}$ La participación de la sociedad civil en el marco del nuevo modelo de desarrollo nacional y regional. Centro Argentino de Estudios Internacionales Programa Política Exterior Argentina. Página 21

48 Ibidem. Páginas 21-23
} 
Comissão Permanente de Representantes do Mercosul (CRPM). Esse encontro repercute no aumento da transparência e da eficiência das decisões tomadas em nível governamental no Mercosul ${ }^{49}$.

O debate sobre a representação da sociedade civil corre o risco de fomentar visões sem dinâmica própria. Os representantes da sociedade civil envolvidos no processo da integração da região são sempre os mesmos. Não há uma renovação, uma ampliação no quadro de pessoas interessadas em se engajar no assunto. Esse fato acaba levando a uma mesmice em torno dos temas discutidos, quer dizer, o debate torna-se limitado. Há somente uma repetição nas discussões dos problemas, os quais não são solucionados. A falta de renovação dos protagonistas e a repetição dos discursos levam a crer que a cúpula tenha perdido a sua função como plataforma de diálogo ou que haja seu esgotamento como instrumento de comunicação.

Além disso, o método da Cimeira Social mostra gradualmente fraqueza. O instrumento de diálogo corre o risco de cair na rotina ${ }^{50}$. Isso se reflete nas reuniões paralelas que acontecem fora do circuito da Cúpula Social. Em 2008, na cidade de Salvador, capital da Bahia, foi realizada em paralelo à cúpula a Cimeira dos Povos das América Latina e do Caribe ${ }^{51}$. O encontro foi organizado separadamente pelos sindicatos regionais de todo o Mercosul. $\mathrm{O}$ fato de os sindicalistas não participarem da Cúpula Social demonstra um problema de identidade ou falta de identificação com a cúpula. Isso quer dizer que o método atualmente utilizado não é suficientemente eficaz a ponto de fazer todas as organizações sociais se unirem. A conclusão que resulta disso é: a Cimeira Social não tem conseguido alcançar seu objetivo. Ela está perdendo sua força inicial e a sociedade civil vem se distribuindo em categorias.

Outro ponto importante que reflete a sua fraqueza é a pequena participação do governo na Cúpula Social. Nenhum presidente participou até agora desse evento, e poucos funcionários do Ministério das Relações Exteriores se interessaram por ela.

\footnotetext{
${ }^{49}$ Vaz, Dorian. Brasiliens Außenbeziehungsministerium; Entwicklungsministerium und generelle Sekretarie der Republik Präsidentschaft. MERCOSUL Social e Participativo. Construindo o MERCOSUL dos povos com democracia e cidadania. Ibraes, 1Ed. Brasilia, 2007. Página 12-15

${ }^{50}$ Aguierre, Maria Julia. Seminar: La sociedad civil y la reforma institucional en el Mercosur (Powerpoint). MERCOSUR Social y Solidario. Datum: 24. und 25. November de 2008 CEFIR: Montevideo 2008. Seite 20

${ }^{51}$ Disponível em: http://www.asc-hsa.org/node/671. Acessado em: 25.12.2008.
} 
Fica evidente que falta compromisso do governo em enfatizar o papel da Cúpula Social para o desenvolvimento do Mercosul.

Uma fraqueza estrutural da cúpula está no seu próprio calendário. A reunião é prevista para acontecer uma vez por semestre, o que demanda investimento financeiro alto e investimento logístico volumoso, já que se trata de fazer trazer para uma mesma cidade pessoas de diferentes países da América Latina. A cúpula acontece no país que exerce a presidência Pro Tempore. A concentração de tarefas de ordem administrativa em um só país acaba sendo desgastante. Melhor seria organizar uma reunião de cúpula anualmente.

A cimeira do qual falamos sofre uma redução no ritmo de criação de instrumentos para a participação social. Dois ou três dias não são suficientes para aprofundar a discussão sobre diversos temas.

Os instrumentos já existentes de integração precisam ser reformulados para que consigam continuar desempenhando seu papel e, como já dito antes, precisam integrar o governo nesse processo de diálogo. A Cúpula Social precisa ser repensada no que concerne seu planejamento e sua execução. Tal mudança deve ser feita pelo Conselho, já que alguns pedidos ou propostas já foram feitos pelo atores sociais, sem êxito até agora.

\subsection{Obstáculos à Iniciativa Somos Mercosul ${ }^{52}$}

Diferentemente do que se passou nos anos 90, quando o acordo de livre comércio norteava a direção da integração regional, hoje o Mercosul caminha em direção dos objetivos da Iniciativa Somos Mercosul, baseados mais na integração da cadeia de produção, na superação do desequilíbrio regional, no uso da política social e na reivindicação de uma maior participação da sociedade civil ${ }^{53}$ de cada país membro. Como resultado dessa nova orientação, o bloco passou, nos últimos anos, a enfatizar

\footnotetext{
${ }^{52}$ Reforma Institutional del Mercosur Análisis de un Reto Nummer 1. CEFIR: Montevideo, 2008. Página 17

53 MERCOSUL Social e Participativo. Construindo o MERCOSUL dos povos com democracia e cidadania. Ibraes, 1 Ed. Brasilia, 2007. Página 12-15
} 
seu trabalho na promoção da participação social e na construção de políticas públicas.

Desde sua criação, são evidentes os êxitos alcançados pelo Mercosul. Mas as dificuldades do bloco se refletem no andamento da Iniciativa Somos Mercosul. O calcanhar de Aquiles do Mercosul é a transparência na comunicação. Outro Ponto é a regulamentação sobre o uso dos meios públicos como meio de comunicação com a população da região sul-americana. Não existem citações ou partes delas nos seus acordos POP ou TA. Os eventos não são anunciados na internet e um grupo limitado tem acesso às informações sobre o bloco. Os problemas de transparência no funcionamento do Mercosul também não são menos graves. As decisões são pouco divulgadas e as negociações não são publicadas, o que contribui para o surgimento de dificuldades da participação das organizações no processo de decisão. A maioria dos sites relacionados ao Mercosul estão desatualizados.

Com essa falta de transparência, o cidadão não está em posição de influenciar nas decisões políticas do bloco. Além disso, o bloco sul-americano sofre com um grande problema, relacionado ao abismo entre o discurso oficial e as ações dos governos. Se analisarmos as declarações com base, os documentos, os acordos, os entendimentos e os discursos dos políticos temos a impressão de que a sociedade civil e o governo querem o mesmo que eles. Agravando essa situação, está o fato de que os governos chegam a violar as suas obrigações como bloco que deve funcionar como um mercado comum $^{54}$, um exemplo é um acordo bilateral de um país do Mercosul com um outro país terceiro.

Não se sabe como as sugestões da sociedade civil são vistas e como poderiam influenciar no processo de decisão. Essa questão do aproveitamento das propostas mostra uma deficiência do regime e do funcionamento dos diversos mecanismos de diálogos. Em 2005, uma decisão GMC n ${ }^{\circ}$ 88/05 estabeleceu que todos os documentos devem ser publicados. A determinação não é cumprida ao pé da letra, como podemos comprovar a partir de um exemplo, que citamos aqui para ilustrar o problema. Entre janeiro 2003 a novembro de 2005 ocorreram 45 reuniões de órgãos decisórios do

\footnotetext{
${ }^{54}$ Programa MERCOSUR Social y Solidario (PMSS). Hacia un MERCOSUR Ciudadano. Los Retos de una Institutionalidad. Seminario: "Sociedad Civil y Nuevas Institucionalidades democráticas en América Latina: Dilemas yPerspectivas" Montevideo, 2008. Pag. 19-20.
} 
Mercosul, CMC e GMC. Nesse espaço de tempo foram produzidos 382 documentos, dos quais 235 documentos são secretos.

A iniciativa tem como função servir como plataforma para discussão da sociedade civil sobre o processo de integração. E por isso mecanismo desenvolvidos pela iniciativa, como o Boletim Somos Mercosul é importante na divulgação da informação sobre os processos de integração e seu desenvolvimento.

\section{A concentração de poder no Mercosul}

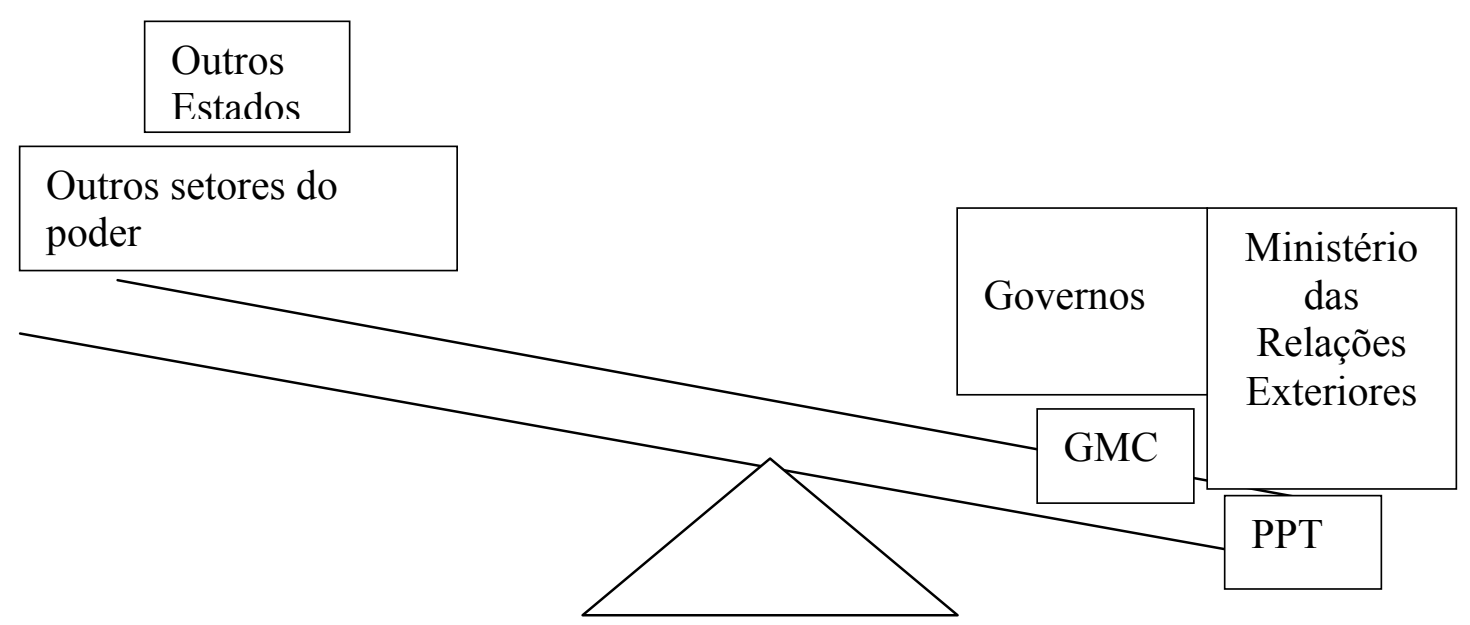

Fonte: Cefir: Montevidéu, 2008.

A ilustração acima mostra como estão distribuídas as forças nas reuniões de decisões do Mercosul. Como se pode ver, existe uma concentração de poder no Executivo, ou seja, as decisões do Mercosul são tomadas pelo $\mathrm{GMC}^{55}$ com o governo de cada país membro-pleno, em conjunto com a chancelaria e a presidência Pro Tempore (PPT), o que representa uma das dificuldades para a iniciativa da qual tratamos neste trabalho. O Mercosul ainda se debate dentro de uma esfera intergovernamental, tornando-se assim dependente de burocracias nacionais. Apesar da participação de todos os Estados-membros nas decisões tomadas pelo GMC, cada país possui um voto, ou seja,

\footnotetext{
${ }^{55}$ O Grupo Mercado Comum (GMC) é o órgão decisório executivo do Mercosul. Ele é responsável de fixar os programas de trabalho, e de negociar acordos com terceiros em nome bloco.
} 
os quatros países possuem o mesmo poder de decisão, porém todas as resoluções são tomadas por consenso, como no Conselho de Segurança da ONU. Não se trata de um sistema institucional transnacional entre os governos e com a participação de diversos setores da população do Mercosul, mas, sim, de uma concentração do poder de decisão, que está sobre o Poder Executivo de cada país. Isso significa que as resoluções do Mercosul são criadas particularmente por certos órgãos dos governos, como o Ministério das Relações Exteriores dos governos nacionais. Consequentemente, temos afinal a posição de um país influenciada por uma visão mais a nível interno e defendendo o interesse nacional. ${ }^{56}$

O Estado concentra o seu poder sobre os setores da burocracia nacional. No caso do Mercosul, a instituição com mais força e autoridade é o já citado Ministério das Relações Exteriores. Ele tem a responsabilidade de representar a política externa do país (sua função é trabalhar para o interesse da nação e defendê-lo em suas negociações). Ele tem a função, em conformidade com os artigos VII, XI e XVII do Protocolo de Ouro Preto (POP), de coordenar e protocolar todas as reuniões do bloco. Importante lembrar que o POP é o protocolo que institucionaliza o Mercosul e dá uma larga margem de poderes a casa diplomática de cada Estado. Isso é uma evidência da concentração de poder dada aos mecanismos internos, responsável pelo posicionamento da política externa do país e por defender seus interesses diante de outros países. O Mercosul recebe assim como herança uma parte da burocracia nacional de cada Estado-Membro pleno que desdobra no âmbito dos órgãos decisórios do Mercosul a realidade burocrática nacional ${ }^{57}$.

Outro aspecto que marca semestralmente as atuais políticas e as decisões do bloco é a presidência Pro Tempore. O país da Presidência Pro Tempore convoca a reunião ou assembléia. Como anfitrião, é ele quem determina a agenda, a dinâmica do semestre e os temas a serem discutidos. O modus operandi de cada Presidência Pro Tempore qualifica afinal o progresso da institucionalização do Mercosul, pois cada pais possui suas próprias prioridades. A concentração de poder compromete a institucionalidade do Mercosul. As instituições com poder de decisão são retratadas na figura da página

\footnotetext{
${ }^{56}$ Ibidem.

${ }^{57}$ Reforma Institutional del Mercosur Análisis de un Reto Nummer 1. CEFIR: Montevideo, 2008. Seite 18
} 
anterior. Elas são o GMC, PPT, Ministério das Relações Exteriores e os governos. Como conseqüência, o Mercosul criou uma dependência de outras instituições. Um exemplo é a entrada de novos sócios, como é o caso atual da Venezuela. A decisão da aderência desse país nesse mercado comum será decidida pelo Congresso Nacional de cada país membro-pleno. Isso significa que a entrada da Venezuela será decidida por uma outra instituição que nem pertence ao organograma oficial do bloco. Para a Iniciativa Somos Mercosul é difícil fortalecer a participação da sociedade civil em uma estrutura como a apresentada pelo Mercosul atualmente.

A iniciativa tem grande capacidade de articulação, mas lhe falta poder de decisão. O projeto precisa de uma forte ligação e de um diálogo ativo com as agências nacionais e intergovernamentais. Infelizmente, os mecanismos, como a Cúpula Social, não são suficientemente influenciadores a ponto de estabelecer essa ligação. Como dito anteriormente, ainda há pouca participação do Poder Executivo, que é a base do bloco, dentro da Iniciativa Somos Mercosul. Ela mesma tem acesso restrito aos resultados de institucionalização do bloco, e por isso se esbarra em dificuldades para consolidar a institucionalização do Mercosul. A concentração de poder nos órgãos nacionais do bloco sul-americano divulga uma perspectiva nacional para o Mercosul, que compromete seu pensamento regional, que é o motivo de existência do bloco.

Outro ponto de limitação do Somos Mercosul está ligado à sua dependência à estrutura da iniciativa no país. Se o órgão que é responsável pelo desenvolvimento da iniciativa está a nível nacional com o compromisso do discurso da sociedade civil. A qualidade e intensidade do desenvolvimento da iniciativa pode vir a diminuir ou a crescer, a depender do nível de engajamento, de estrutura independente e do nível da organização da sociedade civil do país. Seus esforços diante da iniciativa não devem se concentrar apenas na esfera nacional durante a presidência Pro Tempore do seu país. Pelo contrário, toda a sociedade civil devem participar da organização dos eventos dentro de uma presidência, não importa que país esteja assumindo a função no momento. A sociedade civil regional, em parceria com os governos, podem encontrar de forma conjunta as fragilidades da institucionalização do Mercosul e da iniciativa e podem levar a uma solução comum. O relacionamento entre estes dois setores, no entanto, ainda é fraco, apesar dos esforços e dos logros feitos por Somos Mercosul. 
Ainda enumerando as dificuldades enfrentadas pelo projeto Somos Mercosul, entramos na questão da sua fraca institucionalização. A falta de transparência (o deficit de informação dentro e fora da iniciativa), a concentração do poder, a dependência da Presidência são, afinal, resultado de uma iniciativa nãoinstitucionalizada. Ela não tem estrutura supranacional, quer dizer, regional. Sendo assim, falta-lhe segurança para a sua existência e a sua continuação, o que só poderá mudar se os governos assumirem tal compromisso. A iniciativa sofre também com a falta de um orçamento assegurado para se desenvolver de forma independente e sozinha. A iniciativa só é mais independente no Uruguai, graças ao Cefir, organismo não-governamental, que tem a capacidade de promover eventos e discussões em nível "mercosuliano".

Quando a Iniciativa Somos Mercosul foi criada, todas essas dificuldades apresentadas acima já eram vislumbradas. Pensava-se, no entanto, que a iniciativa seria capaz de transpô-las mais facilmente. Fica claro que, para sublimar as dificuldades, é preciso reorganizar a iniciativa e criar uma nova estrutura no Mercosul, que estimulem a dinâmica e dêem maior poder de intervenção nas decisões para a sociedade civil. Para que haja uma distribuição do poder nas decisões do bloco, deve ser assegurada a participação da sociedade civil com independência de outros órgãos na composição oficial do Mercosul, o que significa institucionalização da iniciativa.

\section{Conclusão e a oportunidade para a Iniciativa Somos Mercosul em conjunto com o governo alemão}

O novo contexto político dado ao Mercosul a partir de 2003, que foi acompanhado pela chegada de novos governos com diferentes orientações políticas no poder na Argentina e no Brasil, foi oportuno para a integração do bloco. A nova orientação política se reflete na criação do Programa de Trabalho 2004-2006 do Mercosul, na assinatura do Consenso de Buenos Aires e no evento "Contra Cumbre 2005" com temas sociais em Mar del Plata, que vem sendo realizado em paralelo à cimeira presidencial do Mercosul. 
Essa orientação política centrou-se não apenas na integração econômica, mas também política, social e produtiva da região. Os governos reconheceram a importância que a participação da sociedade civil representa para o alcance da tão desejada integração regional. A participação da sociedade civil não é o único caminho para a criação de uma efetiva integração regional e da democracia, mas é essencial para sua sustentabilidade.

Em resposta aos desafios do bloco, a Iniciativa Somos Mercosul foi lançada pelo presidente Tabaré Vazquez (Uruguai), durante a presidência Pro Tempore do Uruguai em 2005. Isso foi favorável para o desenvolvimento do Mercosul. Os governos apresentaram, após um longo período de silêncio, o que foi caracterizado pela política de auto-regulação. Implantou-se a partir daquele momento uma nova atenção e um novo compromisso com o progresso da integração.

No início, o projeto do Somos Mercosul era apenas uma agenda com eventos, tendo como objetivo a aproximação da população do bloco. Posteriormente, a agenda seguida por outros governos evoluiu para um programa. A iniciativa define-se como uma plataforma na qual a sociedade civil cria uma conexão com os governos dos países membros. "A plataforma Somos Mercosul é um bom aliado com a participação da sociedade civil para a integração regional, enquanto o Frankenstein institucional, que constitui o Mercosul atual, é tão grande quanto ineficiente." 58

O projeto tem o desejo de aproximar os cidadãos do processo de integração e de tentar institucionalizá-lo. Com uma base profunda e uma agenda expandida, a iniciativa se mostra particularmente importante para a abertura de um novo modelo temático do sistema regional. Os coordenadores dos Pontos Focais, os funcionários dos Ministérios das Relações Exteriores e dos Estados-Membros e a sociedade civil trabalham em conjunto para o fortalecimento do processo de integração regional, assim como para a formação e afixação dos promotores da integração regional. ${ }^{59}$

Desde a sua criação, a iniciativa alcançou muitos objetivos. Em geral, pode-se

\footnotetext{
58 Padrón, Alvaro. América Latina Desafios de su Inserción International. MERCOSUR, nuevos actores, nuevas agendas. CLAEH: Montevideo, 2007. Pag. 110

${ }^{59}$ El MERCOSUR por dentro. Páginas 46-52.
} 
observar sua criação e sua continuação, em si, como um sucesso para a sociedade civil. Além disso, ela ajudou no desenvolvimento do Parlamento do Mercosul, da Cúpula Social e do Boletim Somos Mercosul. Esses dois últimos são mecanismos internos da própria iniciativa abordada e todos três mecanismos citados representam um grande avanço na articulação da sociedade civil e no fortalecimento de sua participação dentro do processo. Na minha opinião, a iniciativa é um sucesso e ela se encontra ainda em vias de se concretizar. É a primeira iniciativa regional a ser realizada. Houve, como já referido, a iniciativa brasileira Encontro com o Mercosul (2004-2005) e a criação da instituição argentina Consejo Consultivo la Sociedad Civil, mas os dois projetos constituíram-se dentro de uma esfera apenas nacional.

A criação da Cúpula Social em dezembro de 2006 foi o destaque da iniciativa em termos de criação de um espaço aberto e de uma ponte entre o governo e a sociedade civil. Fazendo um balanço da iniciativa, deve ser observado que, em particular entre 2005 e 2006, houve grande desenvolvimento e largo progresso na iniciativa. Logo depois, a euforia desapareceu, e ela entrou numa fase de afirmação, seguida de uma crise na sociedade civil, pois os verdadeiros obstáculos mostraram-se nos bastidores do "novo" Mercosul.

Somos Mercosul é uma iniciativa ainda jovem, que só existi há três anos. Ela se encontra em uma fase de construção, melhor dizendo, em uma fase de aprofundamento, assim como outras instituições sociais e órgãos do Mercosul. É no entanto evidente que a iniciativa tem fraquezas. As dificuldades do bloco Mercosul, contra as quais a Iniciativa Somos Mercosul foi apresentada como um possível paliativo, essas agora impedem o seu próprio desenvolvimento.

Após uma promissora fase inicial de "Revitalização do Mercosul” (2000), tornou-se evidente que as expectativas associadas a essa dinâmica de integração eram por demais otimistas. Atualmente, impasses no âmbito do bloco provocam desaceleração no seu andamento e no da iniciativa.

A iniciativa criou um espaço para as organizações da sociedade civil, tais como a Cimeira Social, mas este processo deve continuar sendo desenvolvido. Da minha perspectiva, concordo com o desafio de aprofundar a iniciativa. A cúpulas devem 
integrar as discussões de todos participantes, tanto governamentais como nãogovernamentais, para enfrentar as dificuldades da iniciativa e encontrar soluções comuns para o seu desenvolvimento. Além disso, o governo e também outros funcionários do Ministério das Relações Exteriores, e não apenas os Pontos Focais, devem fazer parte da iniciativa de forma mais intensa. A Cúpula Social é uma boa oportunidade, financiada pelos governos, de reunir a sociedade civil regional. É por isso que a iniciativa deve ser aproveitada para lançar novos desafios e assim continuar a dar um impulso à relação entre governo e sociedade civil.

Em outubro de 2008 foi criado durante a presidência Pro Tempore do Brasil um excelente incentivo para a iniciativa. O programa Mercosul Social e Participativo foi elaborado como uma extensão do Somos Mercosul, mas de extensão nacional. A institucionalização da participação da sociedade civil em nível nacional é um processo contínuo da Iniciativa Somos Mercosul. De acordo com o discursos dos representantes governamentais, a idéia é fortalecer a iniciativa nacionalmente para lançar com bases nacionais a base regional.

$\mathrm{Na}$ minha opinião, porém, o primeiro passo de aprofundamento da iniciativa seria o desafio da sua institucionalização a nível regional. O desenvolvimento de uma iniciativa com bases nacionais iria frear suas evoluções, a mesma problemática que já ronda o bloco, que a interferência dos interesses nacionais. A minha idéia inicial seria organizar uma sede para a iniciativa, tornando-a um órgão supranacional. Isso já deu certo no Uruguai com o Centro de Formación para la Integración Regional. O Cefir é uma organização independente, não-governamental, com sede na região.

A sede da iniciativa precisa ter seus próprios empregados com representações de cada pais, uma agenda e um orçamento fornecido por cooperações internacionais, mas grande parte pelos seus governos. Essa nova situação daria uma nova característica a iniciativa e somente depois a expandiria depois a níveis nacionais. Alguns atores do Mercosul, já demonstraram seu desejo de ter instituições fixas da iniciativa na região.

A crise econômica global em 2008 que abalou o mundo gerou desconfiança das instituições sociais para que não ocorresse o mesmo da crise de 2001. A resposta dos governantes do Mercosul foi outra. Os países membros tentam em conjunto enfrentar 
a crise. $\mathrm{Na}$ cúpula presidencial em dezembro de 2008, eles mostraram que não queriam repetir os mesmo erros do ano de 2001, quando esqueceram o Mercosul e centraram-se na problemática nacional. Os governos do Mercosul resolveram enfrentar a crise em conjunto com os países da America Latina e pela primeira vez todas as nações a partir México até a Terra do Fogo estiveram presentes e discutiram resoluções para a crise. Essa reunião ficou conhecida como a Conferência dos países da America Latina e o Caribe (CALC).

Ela lançou esperanças e novos desafios para uma extensão alargamento do Mercosul. A presidência Pro Tempore em 2009 foi acompanhada por grandes expectativas e vitórias. Em julho de 2009, o novo presidente do Paraguai Fernando Lugo, eleito diretamente, realizou a primeira Cúpula Social no Paraguai. Ele apelou para um novo paradigma de integração do Mercosul e da igualdade entre os povos e os países membros, medida que foi importante para a iniciativa no Paraguai, onde também ainda é insuficientemente institucionalizada.

Em março de 2009, na cerimônia de aniversário do Mercosul, foi distribuído pela CRPM um documento com propostas e análises das reformas institucionais do Governo do Mercosul. O Cefir também desenvolveu na época, em colaboração com outras instituições como InWent, um programa entre o período 2009-2012. Tal programa abrange diversos temas, mas tem como foco na integração regional. $\mathrm{O}$ programa vem trabalhando sobre os pontos fracos do Mercosul, a comunicação, a falta de transparência, meio ambiente- tema das energias renováveis, o qual abre novas dinâmicas para discussões. Na minha opinião, esse programa tem o potencial de Cefir e a capacidade de dar novo impulso à iniciativa. O novo programa demonstra a disposição do governo alemão em expandir sua cooperação com a região e abrir outros temas para debate e um fortalecimento da iniciativa dentro do âmbito de cooperação para o desenvolvimento. O comprometimento com a continuação do apoio a uma das sedes do Somos Mercosul.

Depois da grandes cartadas e fechamento de importantes temas no ano 2009 para o Mercosul e para iniciativa, que tanto foram esperados, como a abertura do Instituto Social em Assunção ou a renegociação do preço da energia de Itaipu. O ano de 2010 começa com novas promessas, o governo do Paraguai que antes se mostrava não 
aberto a uma modificação na representação para o Parlamento do Mercosul. Mostra agora abertura de renegociar principalmente com Brasil a margem de representação de parlamentares por país. A iniciativa se expande com novos cooperantes. A iniciativa em conjunto com Cefir-InWent expande com a promessa de um acordo entre o centro e a Fundação Carolina, agência de representação da cooperação para o desenvolvimento do governo da Espanha. O acordo é uma colaboração entre as três organizações no marco da Red Anti-corrupcao do Mercosul, projeto que promove a Good Governance na região.

Em julho de 2010, o Brasil terá mais uma vez a presidência Pro Tempore do Mercosul, em clima de eleição. No Uruguai, seu novo presidente Mujica já mostrou engajamento para a continuação da iniciativa: "morremos juntos, pois todos Somos Mercosul". No entanto, a eleição presidencial brasileira ainda está em aberto e existe um temor em torno do destino do bloco. Por esse motivo a institucionalização da iniciativa Somos Mercosul significaria uma segurança para a sua continuidade. O impulso dado pelo Paraguai, com a realização de sua Cúpula Social e a abertura ao diálogo para o tema da representação no parlamento, mostram que a iniciativa pode continuar sendo exitosa.

Nenhum Estado pode enfrentar muitas outras questões candentes de hoje sozinho. A nossa vida tornou-se mais do que nunca intimamente interligada com a de pessoas de outros países. Portanto, temos também de enfrentar nossos desafios em conjunto: principais alterações são necessárias no mundo inteiro. O governo alemão enfrenta esta responsabilidade. Um dos principais instrumentos para atingir esses objetivos é o desenvolvimento. Porém, a política de desenvolvimento alemã no Mercosul só poderá cumprir sua missão, já exposta, se - em conjunto com seus esforços em nível internacional e nacional para implementar os acordos já feitos com uma gestão diversificada e coordenada, flexível e eficaz - corresponderem à realidade do país cooperante.

No último mês de março, a visita do Ministro alemão das Relações Exteriores, Westerwelle, aos países do Mercosul veio fortalecer o interesse do governo na região. Ele afirma que a região é um parceiro-chave da política externa alemã. Além disso, ambos compartilham de princípios como o valor da liberdade pessoal e o bem-estar 
dos indivíduos. É por isso, de acordo com o seu discurso, que a cooperação da Alemanha com os países da América Latina é muito importante para esse país europeu, pois a cooperação é uma forma de encontrar soluções comuns para problemas globais. 


\section{Bibliografia}

\section{Jornais}

\subsection{Argentina}

Clarin, Buenos Aires http://www.clarin.com/

La Nación, Buenos Aires http://www.lanacion.com/

Felix Peña http://www.felixpena.com.ar/

Mercosur-ABC, 25/07/06 http://www.mercosurabc.com.ar/seccion.asp?IdSeccion=2

\subsection{Brasil}

Estado de São Paulo, São Paulo http://www.estado.com.br/ Folha de São Paulo, São Paulo http://www.uol.com.br/fsp/ Gazeta Mercantil Latino-americana, São Paulo http://www.gazeta.com.br/ Jornal do Brasil, Rio de Janeiro http://www.jb.com.br/

\subsection{Chile}

El Mercurio, Santiago de Chile http://www.mercurio.cl/

\subsection{Alemanha}

Frankfurter Allgemeine Zeitung http://www.faz.de/ Handelsblatt, Düsseldorf http://www.handelsblatt.de/

Süddeutsche Zeitung, München http://www.sueddeutsche.de/

\subsection{Paraguai}

Última Hora, Asunción http://www.ultimahora.com.py/

\subsection{Uruguai}

Brecha, Montevidéu http://www.chasque.apc.org/brecha/

Bolletín Somos Mercosur http://www.somosmercosur.org/

El Observador, Montevidéu http://www.zfm.com/observdiario/

El País, Montevidéu http://www.diarioelpais.com/

La Diária http://www.ladiaria.com.uy/

La República, Montevidéu http://www.diarioelpais.com/ 


\section{Dissertações, textos e literaturas}

Aguierre, Maria Julia. Seminar: La sociedad civil y la reforma institutional en el MERCOSUR. MERCOSUR Social y Solidario. Data: 24 e 25 nov. de 2008 CEFIR: Montevidéu 2008.

Beck, Johannes. Diplomarbeit MERCOSUR: Ergebnisse und Aussichten der regionalen Integration in Südamerika. Studiengang: Regionalwissenschaft. Colonia, 1998. Páginas 1-15.

Betto, Frei.La ética de las ideas, Un mundo mejor es posible. Ediciones Le Monde diplomatique. Buenos Aires, Janeiro 2003.

Caetano, Gerardo (2004) Los retos de la nueva institucionalidad del MERCOSUR. Fundación Friedrich Ebert, Montevidéu.

Caetano, Gerardo/Vazquéz, Mariana/Ventura, Deisy (2008), Reform Institucional del MERCOSUR. Análisis de un Reto. Centro de Formación para la Integración Regional (CEFIR) N. ${ }^{\circ}$, Montevideo 2008, Pag. 39-53

Casal, Óscar. (2005) El camino hacia el Parlamento del Mercosur, Fundación Friedrich Ebert, Uruguay.

Chiappini, Ligia/ Hauck, Jan David (Org.) MERCOSUL/MERCOSUR, Dynamik der Grenzen und kulturelle Integration. Institut für Brasilienkunde, Mettingen- Mettingen: Brasilienkunde Verlag, 2007. Pag. 247-276.

Ehrlich, Ricardo. Politicas de integracíon regional. Experiencia locales exitosas en el MERCOSUR. Montevideo. Tadil, Argentina 2007. Pag. 21-47

Geneyro, Rubén Alberto/ Vázquez, Mariana (2007), El MERCOSUR por dentro. Plataforma Interamericana de Derechos Humanos. Colección Integratemas N. ${ }^{\circ} 6$. Bogotá, 2007. Pag. 17-34.

Konrad Adenauer Stiftung / Consejo Uruguayo. Reflexiones para un MERCOSUR viable.Programa Estado de Derecho para Sudamérica. Montevidéu, 2006.

Olmedo, Maria Jaque. Politischer Jahresbericht Cono Sur 2005/2006. Heinrich Böll Stiftung. Regionalbüro Brasilien und Cono Sur. Rio de Janeiro, 2006. Pag. 5

Padrón, Alvaro. América Latina Desafios de su Inserción International. MERCOSUR, nuevos actores, nuevas agendas. CLAEH: Montevidéu, 2007 Pag. 103-112

Pereira, Marcelo . Ser y Parecer. Balance de la Initiativa Somos MERCOSUR. Anális y Propuestas. Stiftung Friedrich Ebert, Montevidéu 2006.

Propuesta Cumbre Social PPT BR 2008. Actividades InWent / CEFIR "Programa Cohesión Social en el MERCOSUR" en cooperación con la Asesoria para Asuntos Internacionales de la Secretaría-General de la Presidencia de la República Federativa del Brasil. Montevideú, Marco 2008. 
Programa MERCOSUR Social y Solidario (PMSS). Hacia un MERCOSUR Ciudadano. Los Retos de una Institutionalidad. Seminario: "Sociedad Civil y Nuevas Institucionalidades democráticas en América Latina: Dilemas y Perspectivas" Montevidéu, 2008.

Proyecto de cooperación Secretaria del MERCOSUR y Banco Interamericano de Desarollo. Participación de la sociedad civil y de gobiernos subnacionales en el MERCOSUR. Montevidéu 2005.

Rodriguez, Jorge. Ferraro, Daiana. Esa extrana cos llamada FOCEM. Nuevo Diccionario Mercosur.Revista Dialogo Nr. 24. Mercociudades: Montevideo, Nov. 2007. Pag. 42

Rodriguez,Graciela. A Integração Sul- Americana: UNASUL e ALBA. Processos de Integração Alternativo. Rio de Janeiro, 2007. Pag. 10

Racovschik, María Alejandra. La participación de la sociedad civil en el marco del nuevo modelo de desarrollo nacional y regional. Centro Argentino de Estudios Internacionales Programa Política Exterior Argentina. Flacso: Buenos Aires, dez. 2007. Disponível em: http://www.flacso.org.ar/politicaspublicas/files/monografias /alejandraracovschi.pdf. Acessado em: 24.03.2010.

Schuster, Sandra. Mercosur - vom Wandel erfasst? Gespräch mit Claudia Sánchez Bajo über aktuelle Entwicklungen des MERCOSUR. Lateinamerika Nachricht, Nr. ${ }^{\circ}$ 405. März 2008. Disponível em: http://www.lateinamerikanachrichten.de/?/artikel/ 2723.html. Acessado em: 12.12.2008

Secretaria del MERCOSUR (SM). Vorläufiges Dokument für das Seminar Gobernabilidad Democrática en el MERCOSUR. Mecanismos de Participación Ciudadana en el Proceso de Integración Regional.Pag. 6

Secretaria Geral da Presidência da Republica/ Ministerio das Relacoes Exteriores/ Ministerio de Desenvolvimento Social e Combate á Fome. MERCOSUL Social e Participativo. Construindo o MERCOSUL dos povos com democracia e cidadania. Brasilia, 2007.

Secretaria Geral da Presidência da Republica/ Ministerio das Relacoes Exteriores/ Ministerio de Desenvolvimento Social e Combate á Fome. Encontro com o MERCOSUR. Brasilia, 2008. Página 6-7

Somos MERCOSUR/ Consejo Consultivo de la Sociedad Civil/ Cancillería Argentina. Somos MERCOSUR: La Sociedad y la Integración. Por un MERCOSUR Productivo y Social. Cordoba, Julho 2008.

Sullivan, Arthur. Economics: Principles in Action .Upper Saddle River, New Jersey ,2002. pg. 471 
Tovar, Camilo, Balbis Jorge. Mito y Realidad de la Ayuda Externa América Latina al 2009. Una evaluación independiente de la cooperación internacional al desarrollo. Capitulo VII.La búsqueda de una mayor eficacia en la cooperación al desarrollo entre la unión europea y américa latina. ALOP- México, set. 2009. Pág. 39.

Vaz, Dorian. Eine Zusammenarbeit von Brasiliens Außenbeziehungsministerium; Entwicklungsministerium und generelle Sekretarie der Republik Präsidentschaft und die brasilienischen Sektionen des FCES.

Wachendorfer, Achim. Der MERCOSUR in der Ära progressiver Regierungen . Kuzberichte aus der intenationalen Zusammenarbeit. Referat: Lateinamerika und Karibik. Bonn, 2007. p 1-3

\section{Internet}

Agência de Cooperação do Brasil (ABC). Introdução, Brasília 2010. Disponível em: http://www.abc.gov.br/ct/introducao.asp. Acesso em: 10 fev. 2010

Agência Inwent Brasil. Disponivél em: http://www.inwent.org.br/organizacao.html. Acessado em: 22.02.2010.

Câmara Comércio da Alemanha. Disponível em: http://www.ahk-uruguay.com. Acesso em: 15.12.2008.

Indicadores de Desenvolvimento do Milênio. Banco Mundial e ONU, dez 2008. Disponível em: http://mdgs.un.org/unsd/mdg/Host.aspx?Content=Data/ Regional/latin.htm. Acesso em: 20. 02. 2010.

Ministério das Relacoes Exteriores-Argentina.Disponível em: http://ccsc.mrecic.gov.ar Acesso em: 01.12.2008.

Consejo Consultivo de la Sociedad Social Disponível em: http://ccsc.mrecic.gov.ar/ actualidad.htm Acesso em: 10.11.09.

Cumbre de los Pueblos del Sur. Disponível em: http://www.asc-hsa.org/node/671 Acesso em: 04.12.2008.

Pro Tempore Brasilien.Disponível em: http://www.Mercosul.gov.br. Acesso em: 20.12.2008.

Wakipedia: Disponível em: www.wakipedia.com. Acesso em: 03.12.08.

Wikipedia: Disponível em: http://de.wikipedia.org/wiki/Mercosur. Acesso em: 20.12.08.

Wikipédia, fev.2010. Disponível em: http://pt.wikipedia.org/wiki/Cone_Sul. Acesso em: 12.02. 2010 